\title{
Material evidence? Re-approaching elite women's seals and charters in late medieval Scotland
}

\author{
Rachel Meredith Davis*
}

\begin{abstract}
Medieval Scottish women's seals remain largely unexplored compared to the scholarship on seals and sealing practice elsewhere in medieval Britain. This article has two chief aims. First, it seeks to demonstrate the insufficiencies of the 19th-and 20th-century Scottish seal catalogues as a mediated record of material evidence and the use of them as comprehensive and go-to reference texts within current research on late medieval Scotland. This includes a discussion of the ways in which medieval seals survive as original impressions, casts and illustrations and how these different types of evidence can be used in the construction and reconstruction of the seal's and charter's context. Second, this paper will explore the materiality and interconnectedness of seals and the charters to which they are attached. A reading of these two objects together emphasises the legal function of the seal and shows its distinctive purpose as a representational object. While the seal was used in contexts beyond the basic writ charter, it remained a legally functional and (auto)biographical object, and, as such, the relationship between seal and charter informs meaning in representational identities expressed in both. The article will apply this approach to several examples of seals belonging to 14th-and 15th-century Scottish countesses. Evidence reviewed this way provides new insight into Scottish women's sealing practice and female use of heraldic device. The deficiencies of assuming women's design to be formulaic or that their seals can be usefully interpreted in isolation from the charters to which they were attached will be highlighted. The interconnectedness of word and image conveyed personal links and elite ambitions, and promoted noble lineage within the legal context of charter production.
\end{abstract}

\section{INTRODUCTION}

The seal of Isabella, Countess of Fife (d 1389) features a tree, from which two branches extend downward (Illus 1). ${ }^{1}$ Shields hang from these branches on either side of the tree. Reading the seal from the perspective of the sealer, the dexter (right) shield bears a lion rampant, the arms of Fife, her natal kindred. The sinister (left) shield bears a fess chequy, the arms of Stewart, one of her marital families. ${ }^{2}$ The seal design differs from what we might expect of an elite woman's seal in the Middle Ages. For one, there is no female figure, a predominant feature of women's seals on the Continent and in Britain from the 12th and 13th centuries (Bedos-Rezak 1990: 1-11; Johns 2003: 122-51; Nolan 2009; Johns 2016: 91-104). When considered alongside other elite women's seal designs from the 14th and 15 th centuries, the way in which her identity was constructed bears similarities to other extant seal impressions and casts belonging to Scottish countesses from this period. This article seeks to move discussions of women's sealing

*Associate Staff, University of Dundee RDavis001@dundee.ac.uk 


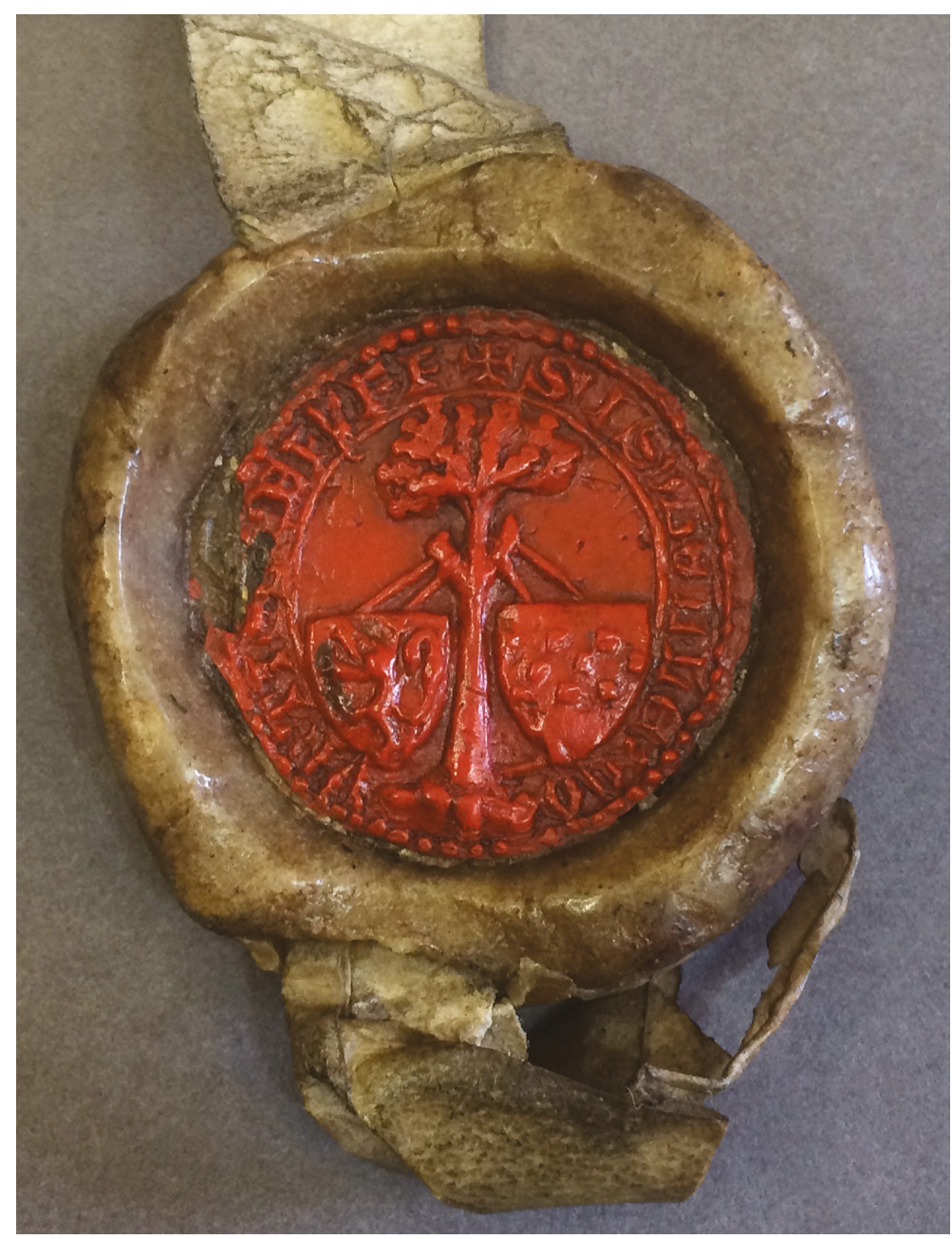

ILLus 1 The seal of Isabella, Countess of Fife. A seal featuring a tall tree, from which two branches extend downwards. Shields hang from these branches on either side of the tree. Dexter: a lion rampant; Sinister: a fess chequy. ( National Records of Scotland)

practice beyond what Bedos-Rezak termed the 'semantics of the female image', showing that the analysis of heritable insignia and its use in elite women's seals is a significant avenue for further research into the ontological meaning of the seal (Bedos-Rezak 1990: 11). This article will offer an analysis of the seals and charters of six countesses: Agnes Randolph, Countess of March; Janet Dunbar, Countess of Moray; Isabella, Duchess of Albany and Countess of Lennox; Margaret Stewart, Countess of Angus and Mar; Euphemia Leslie, Countess of Ross; and Margaret Stewart, Duchess of Touraine, Countess of Douglas and Lady of Galloway and Annandale. The analysis will shed light on how representational identities were constructed by women, and how the written and visual word of text and image might articulate an individual's position within the Scottish elite. The meaning behind seal design differed with the individual, sometimes promoting political links, or reinforcing claims to land or social leadership, or commemorating personal links through stylistic choices. 
Medieval Scottish women's seals remain comparatively under-studied alongside the scholarship on seals and sealing practice in medieval Britain. More generally, Stuart D Campbell recently pointed out that 'the material culture and archaeology of medieval Scotland are familiar from both archaeological excavation and museum collections, although familiarity has often proved an impediment to further understanding' (Campbell 2013: 183). This statement holds particularly true of Scottish sigillographic evidence, which Campbell covered only briefly in his chapter. He assumed that findings of well-established sealing studies in other medieval polities - namely France - could be mapped onto sealing practice in Scotland (Campbell 2013: 192). The relative paucity of study on Scottish sealing material is perplexing, given the efforts of 19th- and 20th-century compilers of seal catalogues, which make Scottish seals a well-known, if understudied, source material. However, the catalogues have been questioned for their authority in recent analysis of Scottish episcopal seals (Bertie 2018). There have been numerous studies on Scottish sealing practice that have focused mainly on the seals of men (Caldwell 1993; McAndrew 1999; Glenn 2007; Holton 2017: 81-2; Neville 2017). While there has been work on English, Anglo-Norman and Welsh women's seals, similar research has not been carried out to the same extent on Scottish women, with the exception of Neville's coverage of 12th- and 13th-century seals belonging to women (Johns 2003: 122-51; Neville 2005: 44-9; Danbury 2008; Johns 2015: 272-9; Johns 2016). The general lack of engagement with Scottish sigillographic material is especially surprising given the proliferation of charter studies in the investigations of lordship and kingship within Scottish historiography (Broun (ed) 2011: xi-xvi; Hammond 2013). This highlights the separateness with which seals and charters are often treated in scholarship. This article seeks to consider seals and charters alongside one another, to ascertain how the imagery of the seal communicated with the text of the charter to convey an individual's power and authority.

To seal and to have a seal was to have agency in the Middle Ages because it provided the user with the materials necessary to conduct legally binding business. The seal 'represented the sealer - indeed - it represented the personhood and real presence of the sealer' in a variety of contexts (Whatley 2019: 4). It was a material object through which identity could be constructed and expressed (New 2013: 332). Elizabeth A New \& Phillipp R Schofield have emphasised the significance of seals in a British context. They argued that seals 'were usually the choice of their owner, and as such provide a unique insight into the personal concerns of women and men across the social spectrum, including those for whom little evidence survives' (New \& Schofield 2016: 1). Seals are therefore an invaluable source for the historian uncovering how elites conceptualised their identity, status and authority and expressed this identity to their peers. However, the legal significance and functionality of the seal in conjunction with the charter, as well as the deployment of heraldic device, repays further analysis in the Scottish context.

This article engages with the 'language' of the seal alongside the charter's text and how the semantics of image and charter articulated the power and authority of the individual. Recent studies have drawn attention to the material culture and the 'language' of elite representation in late medieval and early modern Scotland (Campbell 2013; Buchanan \& Dean 2016; Neville 2017: 113-14). We might consider the intertextual relationship between seal and charter and how the 'language' of charter and seal functioned together in representing an individual's personhood and elite status. Intertextuality theorises a relationship between texts in which a text by itself does not hold independent meaning. As Graham Allen has summarised, 'meaning becomes something which exists between a text and all other texts to which it refers and relates, moving out from the independent text into a network of textual relations' (Allen 2011: 1). Intertextuality has been proposed by Brigitte Bedos-Rezak in her scholarship on both seals and charters. She posited such a relationship between a seal's image and its legend (Bedos-Rezak 1988: 319; 1990: 1). More recently, she has commented on the intertextual relationship between charters 
and their duplicates and later cartulary copies (Bedos-Rezak 2011: 50). She also further highlighted the 'symbiotic relationship' between seal and charter (Bedos-Rezak 2011: 27). This article builds on this scholarship and argues for an intertextual relationships between charter and the attached seal. As a legal document, the seal and charter were interconnected and interdependent, as the seal was necessary in the authenticating process of the charter as diplomatic product. Rather than consider seals independently from the charters to which they were attached, a consideration of charter and seal as communicating in relation with one another provides us with a more nuanced understanding of the strategic and varied use of text and image to convey an elite's status and authority.

This article has two principal aims. First, to show the deficiencies of using Scottish seal catalogues as authoritative texts or as a substitute for archival material. The present study has uncovered new sigillographic material belonging to elite Scottish women in the 14th and 15th centuries, which was previously overlooked in the compilation of these catalogues. The findings of my work on elite Scottish women coalesce with the discrepancies raised by David M Bertie in his work on Scottish episcopal seals, which suggests that a re-investigation of 'new' material might be done for Scottish sigillography more broadly (Bertie 2018). Second, this article will use an intertextual approach to seals and charters. It will argue that the interconnected relationships between Scottish seals and charters in contemporary use provides a greater context for the representational identities expressed in each source separately. When charter and seal are 'read' together, it provides us with further insight into the specific deployment of heraldic device to convey an elite's status and authority. This approach also allows us to ask questions of the source material and provide new contributions to scholarship on women's sealing practice. How did elite women use heritable insignia in their seal designs? To what extent can these objects be read as autobiographical? What do seemingly non-mimetic aspects of seals tell us about elite status and authority?
The body of evidence of seals belonging to women of this period is varied, which makes it difficult to define any one trend among them as 'typical' of female sealing practice. As New \& Schofield have argued, individual choice was a key element of British sealing praxis (New \& Schofield 2016: 1). The one universal element of women's seals from 14th- and 15th-century Scotland is the use of heraldic device(s) to communicate identity. The six examples discussed herein have been chosen as representative of the wider evidence base, but it should be noted that each seal is contextually unique (Davis 2020: 87-155). The six seals discussed are 'typical' in that they show elite women's communication of power and authority through the imagery of the seal and the text of the charter that was particular to their personal and individual ties to noble lineage and the associated privileges afforded by that lineage. This intertextual methodology is not without its challenges. While there are ways in which the context of the seal and charter might be reconstructed, which will be explored here, there are instances when this methodology cannot be applied to elite women's seals from the period. Women's seals that survive only in cast form in the 21 st century, with the charter evidence also lacking, cannot be parsed as two objects working together. However, these instances are a small subset of the 54 seals which were considered in the discussion here, and in most instances, an intertextual reading of seal and charter could be accomplished. The article will show specific examples of how an approach that considers the relationship between seals and charters deepens our understanding of the ways in which elite women communicated their connection to lineage and promoted claims to territory and titles, which was personal to each woman as an individual and member of the Scottish nobility.

\section{SCOTTISH WOMEN'S SEALS IN THE ARCHIVES}

Scottish medieval and early modern seals have long held antiquarian interest and have been extensively catalogued since the 19th century, 
similarly to materials elsewhere in Britain and on the Continent (Whatley 2019: 5-6). Henry Laing published his catalogue in 1850, titled Descriptive Catalogue of Impressions from Ancient Scottish Seals, which was followed by a supplemental volume in 1866 (Laing 1850; Laing 1866). In addition to the printed volumes, he produced resin seal casts from original seal impressions, which are still held by the National Records of Scotland. ${ }^{3}$ This work was taken up again by William Rae MacDonald in 1904, who used these casts to produce a new seal catalogue that included new material. The heraldist quickly published his Scottish Armorial Seals for use by students and researchers but it remained unfinished (MacDonald 1904: x). The compilation work was then resumed in the 1930s by heraldist John Horne Stevenson and Marguerite Wood, who produced the largest of the Scottish seal catalogues. Similarly to Laing, Stevenson \& Wood produced seal casts of original impressions and new seal casts from Laing's 1850 exemplars. ${ }^{4}$ Despite the comprehensive ambitions of Stevenson \& Wood's research, it too remained unfinished. Wood acknowledged in the introductory materials to the volume that the untimely death of Stevenson in 1939 meant that the work published was incomplete (Stevenson \& Wood 1940: iv). Additionally, there was an effort to see it printed before the outbreak of the Second World War and wartime paper scarcity. ${ }^{5}$ Thus, the use of these catalogues as reliable or comprehensive reference texts in research on Scottish sigillography ought to be approached with more caution than has been applied in recent scholarship.

Beyond issues of comprehensiveness, the descriptions within Scottish seal catalogues raise issues of accuracy and antiquarian research practices. Wood addressed the issue of accuracy herself, stating that the descriptions for personal seals as published had only been checked against seal casts up to surnames beginning with ' $\mathrm{C}$ ' (Stevenson \& Wood 1940: iv). There are issues with accuracy with regard to elite women's seals, which can be seen in surnames beyond ' $C$ '. For example, the seal of Margaret Stewart, Countess of Angus, who married John Stewart,
Earl of Angus, had been mistakenly catalogued as belonging to her granddaughter, Margaret Stewart, Countess of Angus and Mar (Stevenson \& Wood 1940: 602). While J P Ravilious and Bruce McAndrew have both recently proved this misidentification through analysis of the heraldry of each, it is worth rehearsing here why it was misidentified (Ravilious 2010; McAndrew 2011: 73). The legend of the countess's seal reads ' $S$ ' MARGARETE SENESCALLI COMITISSE DE ANGOS' (Illus 2). ${ }^{6}$ The misidentification of the countess occurred because of the adoption of her marital surname Stewart (Senescalli) in her seal legend, which was the same surname used by her granddaughter, rather than her natal surname, Abernethy. The countess's seal does not follow expected patterns in naming practice, as she did not retain her natal surname, which is often assumed of women in Scotland in the Middle Ages (Marshall 1983: 21; Wormald 1985: 79; Ewan \& Nugent 2008: 7). Thus, reading seals within the context of their charters, where possible, as well as within their wider historical context helps assess the accuracy of antiquarian catalogues of seal descriptions. The seal cast of Margaret Stewart (née Abernethy) was taken from an impression attached to a charter dated 1366, before her granddaughter, Margaret Stewart, would have been legally old enough to participate in a charter. Furthermore, Katie Stevenson, in her work on medieval heralds in Scotland, has pointed out the general deficiencies in taking texts produced by the Court of the Lord Lyon as authorities. She has argued that the methods with which medieval evidence was considered by 19th- and 20th-century heralds led to anachronistic interpretation (Stevenson 2009: 41). Stevenson's arguments can also be applied to the Scottish seal catalogues, which reflect the assumptions and methods of their compilers and their time. The descriptions of the seals warrant critical engagement and analysis of physical evidence rather than the assumption that they are accurate mediations of archival materials. It is important to emphasise here that the descriptions within seal catalogues are the interpretation of their compilers, rather than a substitute for the primary source material (Bedos-Rezak 2011: 59). 


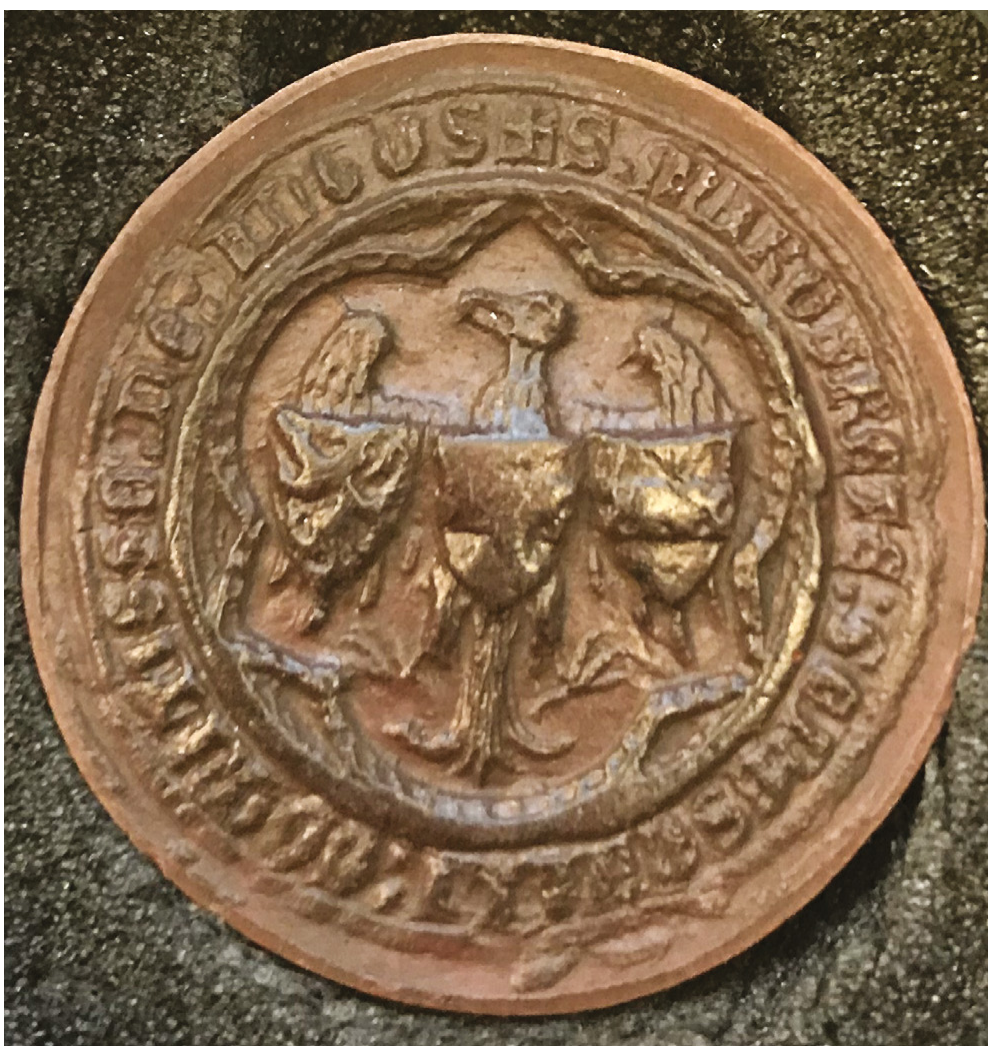

ILLus 2 The seal cast of Margaret Stewart (née Abernethy), Countess of Angus. The seal features an eagle displayed, with head turned to the dexter, bearing on its breast three seals. The eagle and shields are surrounded by tracery. The shields' arms: Centre: possibly a lion rampant (indistinct); Dexter: a lion rampant debruised of a ribbon; Sinister: a fess chequy with a label of five points. (ㄷ British Library Board)

More should be said on the supposed 'completeness' of the Scottish seal catalogues. The exhaustive title of Stevenson \& Wood's catalogue suggests that, even if their findings were not accurate, it represents a seemingly comprehensive survey of surviving material. However, this is misleading. As Neville noted in her own study, with regards to the catalogues, few questions have been asked of the source material (Neville 2010: 85). Indeed, the catalogues have held a position of authority for too long in place of the material evidence. Adrian Ailes has pointed to the potential of finding Scottish material in The National Archives (Kew), and drawn on examples of seals that are not included in Stevenson \& Wood's catalogue (Ailes 2010). The work of McAndrew on the Ragman Roll has been invaluable for adding to our knowledge of heraldic and non-heraldic seals belonging to Scots in English archives (McAndrew 1999). Similarly, Bertie's work on Scottish episcopal seals has highlighted new material (Bertie 2018). My investigation of 14th- and 15th-century elite women's seals has identified one seal cast and six additional seal impressions that do not appear in the Scottish catalogues, including one formerly held by the British Museum, and one of the national depositories consulted by Scottish cataloguers. Additionally, overlooked material has been held by the National Records of Scotland, which was the principal archive for these compilations. ${ }^{7}$ The 'new' material uncovered in this study has broader implications and we might reasonably 
expect more Scottish seals to exist than indicated in the Scottish seal catalogues.

While Scottish seal catalogues do reflect archival holdings, the descriptions of seals within these catalogues are the interpretation of the compiler. As such, these descriptions ought not to be used as substitute reference for archival materials. Not only does the use of catalogues unnecessarily mediate objects through the written record, it also further divorces seals from their original context. When seal and charter are considered together, and preferably in situ, the evidence offers new understandings of Scottish elite identity construction, commemoration, and promotion of claims to noble lineage. The article will trace the ways in which we can analyse seals in context with their charter and also how we might carefully reconstruct their context with the use of seal casts and seal illustrations. Seal casts are reproductions from original seal impressions, and can be used in instances where the surviving evidence is damaged or missing. Seal illustrations are images reproduced to represent extant materials, which might otherwise no longer survive. Both casts and illustrations should be considered preferable to descriptions from catalogues, as they allow for the historian to interpret them as objects, albeit with some contextual loss, rather than rely on the interpretation of catalogue compilers. This article will take care to consider methodological issues in assessing women's seals through the different ways in which their sigillographic material has survived. The article prioritises the physical, material evidence of seals in its analysis of sealing praxis among the six countesses' seals.

\section{A PROPOSED APPROACH TO THE INTERTEXTUALITY OF SCOTTISH SEALS AND CHARTERS}

Charters and their seals have long been associated with the written record (Clanchy 1993). However, charters also functioned beyond their prosaic status as legal-documentary writs that recorded the business of lordship. They also served as commemorative objects of elite status. Neville has emphasised that charters had a 'potent status as symbolic objects' (Neville 2010: 73). The importance of charters as objects can be traced in the sources themselves and can be particularly useful in understanding the culture that created them. Katie Stevenson has argued that 'material culture and customs provide rich resources for study of the representations of authority and the way in which status, position, and lineage were expressed by ritual, objects, and cultural activities' (Stevenson 2014: 182). In a 1404 notarial instrument, for instance, charters played an important role in the symbolic public staging of the marriage of Isabella Douglas, Countess of Mar, to her second husband, Alexander Stewart. The document describes that Stewart presented the countess with Kildrummy Castle and 'all the charters and evidences of the said lady [omnibus cartis et evidentiis dicte domine] with silver vessels [vasis argentis] and other ornaments existing in the castle [omnibus aliis ... in dicto castro] into the lady's hand with all the keys of the said castle'. ${ }^{8}$ The phrasing of the document, listing charters among other items of value - silver vessels and the keys to the castle - belonging to the countess, indicates the importance of charters as commemorative objects of status and authority for medieval individuals. Additionally, it provides us with insight into the performative theatre of elite social display and the use of charter as status symbol (Bedos-Rezak 2011: 50; Weikert 2020: 185). The clause from the Kildrummy notarial instrument provides us with direct evidence of the function and significance of charters within medieval Scottish contemporary society beyond their legal function and how they were used as objects to signal status and authority to their contemporary audience.

The charter operated in conjunction with its attached seal(s) to convey the power and authority of the individual(s) who participated in the document. The seal functioned as literal material witness to an individual's charter and the impression of the seal acted as extension of the owner in the absence of real presence (Bedos-Rezak 2000: 1489). Evidence of this lies in the formula of charters, which included a sealing clause before the testing clause with a variant of the phrase, 'to 
which our seal is affixed as testimony of this our present charter of property [in cuius rei testimonium huic presenti carte nostre nostrum apponi sigillum]'. ${ }^{9}$ The inclusion of the sealing clause elucidates the authenticating function of the seal as legal object. The charter became authentic by the process of being sealed and the 'sealed charter', as Bedos-Rezak has argued, 'was an iconic document in which several systems of signs - the letter, the image, the heraldic emblem - entertained a symbiotic relationship' (Bedos-Rezak 2011: 27). The significance of the seal as authenticating object meant that it acted as witness to the charter and served as representative of the sealer after issuing the charter (Bedos-Rezak 2011: 30-2). The 'symbiotic relationship' argued by Bedos-Rezak between the authenticating seal and its charter thus warrants an investigation into the relationship between these artefacts and the ways in which they operated alongside one another to convey the status and authority of the individual.

Seals ought to be interpreted within the context in which they were used - as authenticating and making legally valid the charter to which they were attached. The images on women's seals - the visual words - operated interdependently with the written words of the charter as well as the seal legend, which all functioned together to assert a woman's authority as a female lord. The claims made within the visual field of the seal were achieved through its contemporary audience's understanding of what the symbols meant (Crane 2002: 2; New 2008: 466). Thus, individual representation in a seal was a means of expression beyond the remits of the individual border of self. The seal functioned as representative of its owner because it was understood and given meaning by its contemporary audience. Identity in the Middle Ages relied on a 'logic of sameness', as Bedos-Rezak has noted, in which an individual conceived of their identity in relation to the group to which they belonged (BedosRezak 2011: 112-13). The symbols used to articulate personhood necessarily held meaning and a semiotic literacy within the group in order for the power and authority of the individual to be understood by the audience (Buchanan \& Dean
2016: 1). Medieval sign theory, derived from Augustine of Hippo's On Christian Teaching, suggested an ability to understand signs, as they functioned in a mutually agreed use (Eco \& Marmo 1989: 4-5; Augustine 1997: 30-100; Bedos-Rezak 2011: 121-8). While Augustine's original interpretation of visual words (verba visibilia) was in the specific context of biblical allusions, it has broader applications to the imagery which features in both heraldic and other iconographical elements of seal designs (BedosRezak 2011: 29). The seal employed the visual vocabulary of heraldry and other iconography in its communication of an elite woman's identity. However, it functioned within a specific and legal context, attached to the charter. As such, the relationship between charter and seal ought to be pushed further. Brigitte Bedos-Rezak has noted the intertextual relationship between sigillographic iconography and the text of a seal's legend, and how text and image operated in conjunction with each other (Bedos-Rezak 1988: 319; 1990: 1; 2011: 27). Bedos-Rezak has further termed this relationship between seal and charter 'symbiotic'. We might read the relationship through the lens of intertextuality because there was an interdependence between seal and charter in communicating individual identity while also authenticating the sealed charter. The seal held meaning as an authenticating object and the charter relied on the seal to confirm its authenticity. Both worked interdependently to create the authentic charter. Thus, the relationship between the seal's visual words (verba visibilia) communicated through heraldry and other iconography and the actual text (verba) of the charter functioned in connection with each other, which, when read together, articulated a specific expression of elite status and authority.

Methodologically, women's seals have often been studied or mentioned alongside other visual media, such as coins, effigies and funeral brasses, as these objects were all commissioned works that conveyed female representations of status, authority, and power (Nolan 2009; Saul 2009: 290-5; Jordan 2015). Barbara J Harris has argued that English women's commissioning of effigies provides insight into women's identity 
and subjectivity in ways that written documents do not, which is an argument that may also be applied to women's seals (Harris 2009: 311). The methodological links between these divergent media have been motivated by questions about women's self-representation and identity construction (Saul 2009: 290-1). While these objects were commissioned works; they functioned rather differently as representational media. As tempting as it is to consider seals alongside other visual and material evidence, this article emphasises the legal function of seal impressions, which separates them from other forms of visual media. This makes the seal a completely different visual and material object than monumental sculpture, clothing, funeral brass or coinage. However, like other commissioned works, women participated in their identity construction represented in their seals, even though this participation was mediated through patriarchal views as much as through conventions of sigillographic representation. When the visual iconographies of their seal designs are considered alongside, and in conversation with, the text of their charters, the meaning and symbology of their sigillographic representation are more fully realised. The evidence being thus treated suggests that elite women made deliberate choices in their heraldic and other iconographic features in order to deliberately convey and corroborate their social position and authority that was put forward in the text of the charter.

The critical engagement with and analysis of women's use of heraldic device in seal designs remains a relatively under-studied aspect of sealing practice for women in the Middle Ages. With the exception of Elizabeth Danbury's work, there has been relatively little attention paid to the use of heraldry in women's seal designs. This perhaps owes something to Bedos-Rezak's 1990 determination that a woman did not participate in the 'heraldic grammar of her patrilineage' (Bedos-Rezak 1990: 6). While her argument was quite specific and focused on marks of cadency, which was a practice that indicated birth order of sons, her overall conclusions were that women were identified through gender alone and that the 'semantics of the female image' was the chief representational iconography in women's sealing
(Bedos-Rezak 1990: 11). Subsequent analysis of women's use of heraldry and the female figure has suggested that women's seal designs were formulaic. In these interpretations, the female figure has been described as the bodily link, a conduit, between the two lineages represented by the heritable insignia (Coss 2000: 73-144; Morsel 2002: 164; Neville 2005: 44-9; Saul 2011: 275). This interpretation of women's seal designs renders them as passive transmitters of elite lineage, social status and authority, rather than active participants as female lords. The analysis that follows provides investigation beyond the 'semantics of the female image'. As will be seen with the examples of the seals of countesses here, the female body was not common in the visual representation of Scottish female elites by the 14th century. As Sophie Harwood recently argued, the analysis of women's use of heraldry has 'the potential to unlock information not just about women themselves, but about the way in which they were perceived and employed within their contemporary environment' (Harwood 2017: 83). While chivalric culture was rooted in participation in noble lineage, the role of women in this key part of aristocratic culture has been under-emphasised in the wider field of chivalric study, and warrants further scholarly attention.

The argument that cognatic and maternal lineages were important to elites in their expression of status and authority perhaps seems obvious. However, heraldry, and chivalric culture more generally, has overwhelmingly been studied within the context of male lineages. This is unsurprising given heraldry's claimed potential origins on the battlefield and the close connection to the recording of martial prowess (Crouch 1992: 220; Caudrey 2019: 1-188). As such, heraldry and heritable insignia were organised by and around male lineage. However, the sigillographic evidence of Scottish noblewomen suggests that they were cognizant of the ways in which seals might visually represent their authority and relationships to multiple noble lineages. Shields communicated concisely both the individual and group identity of a medieval noble (Crane 2002: 20). More recent work, in addition to Susan Crane's, has argued that heraldry came to 
signify a commitment to chivalric values, which was central to aristocratic culture and elite identity (Stevenson 2006: 192; Armstrong 2009: 18). Despite the numerous and varied investigations into chivalric culture, the focus has remained on men and a general decline has been associated with elite women's social positions with the rise of chivalric culture from the 12th century (Saul 2011: 282; Crouch 2019: 305). Female use of heraldic device ought to be reappraised to consider women as active participants within noble lineage and chivalric culture generally, to show the way in which women might manipulate and articulate their own claims to material resources and leadership positions through the deployment of heraldry. Within this framework, the way in which women's seals expressed their relationship to lineage and status becomes essential for understanding how elites conceptualised the public-facing self and communicated this version of the self to their noble peers in both the text of their charters and the imagery of their seals.

INTERTEXTUAL REPRESENTATIONS: THE EVIDENCE OF SEALS AND CHARTERS

Influenced by scholarship on female lordship, work on women's seals has only recently underscored the importance of seals as objects of female status and authority. Johns has asserted that the earlier understandings of lordship and sealing practice within Britain (England and Wales) 'articulated a paradigm that emphasised male power and action and neglected the participation of women in contemporary power structures' (Johns 2015: 272). As has been argued above, the seal was a functional, legal object that was acquired and required for participation within these structures. It is surprising, then, given the fact that charters have been the chief source material mined by women's and gender historians since the 1990s, that the study of women's seals often remains auxiliary to, indeed sometimes entirely missing from, the deliberations of charter scholarship. The seal and charter to which it was attached communicated and represented together the status and authority of an individual. Seals, then, are material remnants and (auto)biographical objects of the medieval elite as well as material evidence, in conjunction with the charters they are attached to, of the individual's participation within contemporary power structures. Thus, seal and charter must be read as intertextual objects to understand the nuanced and complex articulations of elite status that were achieved by word and image, which can be traced in case studies of countesses' seals from 14 th- and 15th-century Scotland.

\section{THE SEALS OF AGNES RANDOLPH, COUNTESS} OF MARCH AND JANET DUNBAR, COUNTESS OF MORAY AND LADY OF FRENDRAUGHT

The seal design of Agnes Randolph, Countess of March (and Moray) is better read within the broader context of the 1367 charter to which it is attached (Illus 3). ${ }^{10}$ The slightly damaged seal features four shields arranged crosswise, coming to a point at the centre of the seal. The seal bears the arms of her natal and marital lineages. Reading the seal from the top, clockwise, it features the arms of Scotland, a lion rampant within a double tressure; the arms of Randolph (Moray), three cushions within a double tressure; and the arms of March and Dunbar, which were the same, a lion rampant in a border charged with eight roses, represented on two distinct shields. The legend is damaged, but reads '...GNETIS CO[M]ITISSE MAR...ET MOR...' which suggests that the legend corresponded to the way in which she was named in the charter as 'Agnes Countess of March and Moray [Agnes comitissa Marchie et Moravie]'. ${ }^{11}$ Thus, the legend corresponded with the text of the charter, which was visually reinforced with the presence of March and Moray as distinct arms in her seal design. The claims to Moray were perhaps exaggerated, as she was the daughter of the Earl of Moray but she did not have possession of the earldom. The other two shields commemorated her relationships to Dunbar (which she designates as separate from March, even though they were one and the same) and her natal lineage, Randolph, and further communicated her status and legal authority through both her marital and natal kindreds. The 


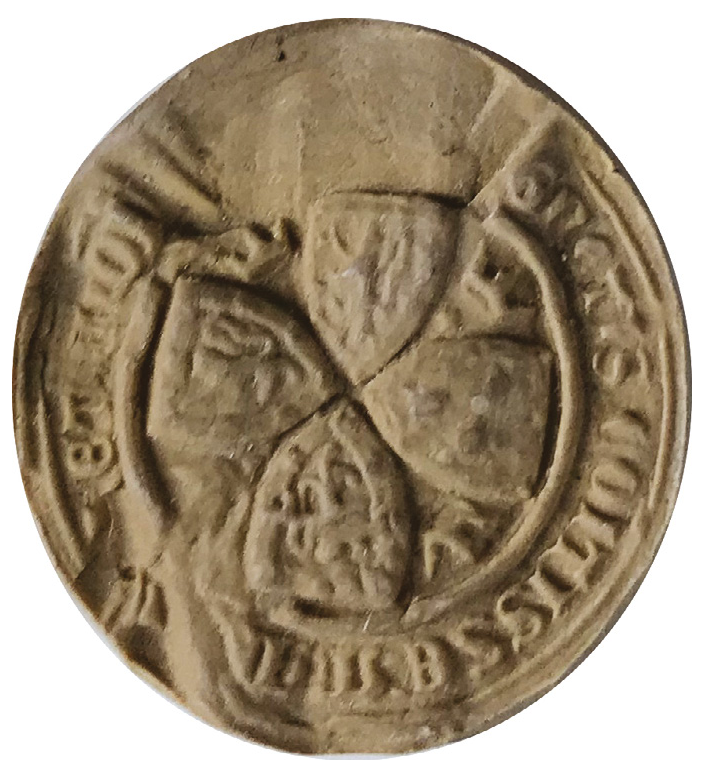

ILlus 3 The seal cast of Agnes Randolph, Countess of March and Moray. The seals feature four shields arranged crosswise, coming to a point in the centre of the seal; between each shield is a crown and cinquefoil. The shields' arms, from top moving clockwise: a lion rampant within a double tressure; three cushions within a double tressure; a lion rampant in a border charged with eight roses. (C) Lyon Office, The Court of the Lord Lyon, Edinburgh; by kind permission of the Lyon Office)

design visually articulates the countess's relationship to each lineage and associated territories and privileges, with the conjoined shields at their bases alluding to Agnes Randolph as the focal point between them.

Agnes's seal design and separated shields can be compared to the seal of Janet Dunbar, Countess of Moray and Lady of Frendraught and Crichton, which was used in the $1450 \mathrm{~s} .{ }^{12}$ The arms quartered in her shield represent her natal and marital lineages, with her seal legend emphasising her connection to Crichton and Moray, 'S' IONETE DE CRE.G..ON COMITISSA MORAWYE'. The use of the Crichton surname differs from the surname used in her charter, where she is designated as 'Janet Dunbar, Countess of Moray and Lady of Frendraught [Joneta de Dunbar comitissa de Moravie domina de Frendraught]'. ${ }^{13}$ The use of the Crichton surname in her seal legend can be read in conjunction with the visual reference to Crichton through the presence of the Crichton arms in her marshalled shield, a lion rampant. The other arms, of Frendraught and Moray, in the seal design visually tie with her title given in the charter. Considered together, the seal designs of Agnes Randolph and Janet Dunbar show the active participation of women in heraldic conventions in order to represent their connections to several lineages, as well as asserting their individual rights to the associated properties and privileges connected to each lineage. Both examples serve as relatively straightforward instances of the interplay of charter and seal with one another in contemporary use, where the visual programme of the seal design communicated with the text of the charter.

\section{THE SEAL OF ISABELLA, DUCHESS OF ALBANY AND COUNTESS OF LENNOX}

Not all late medieval seals can be parsed as easily as the examples above. We might trace, then, seemingly non-mimetic aspects of elite Scottish women's seal designs if we were to consider seals and sealing practice in isolation. There are particular iconographic choices featuring in the seal of Isabella, Duchess of Albany and Countess of Lennox, which from an intertextual perspective on seal and charter, give new meaning to the duchess's seal design and its contemporary use. At first glance, the iconography of her seal, as well as her titles claimed in the charter, seem incongruous given her political circumstances in the 1440s and 1450s. Her seal bore the legend, 'SIGILLU ISABELLE DUCISSE ALBANIE + COMITISSE DE LEVENAX', linking to the title within the charter, in which she was identified as 'Isabella, Duchess of Albany and Countess of Lennox [Isabella ducisse Albanie et comitissa de Levenax]' (Illus 4a, Illus 4b). ${ }^{14}$ Both legend and charter asserted lineages and titles that were claimed through the marshalled arms featured in the visual field of the seal design. The seal survives attached to a charter from 1440, a period following the duchess's incarceration and the execution of her male kin for treason (Bower 


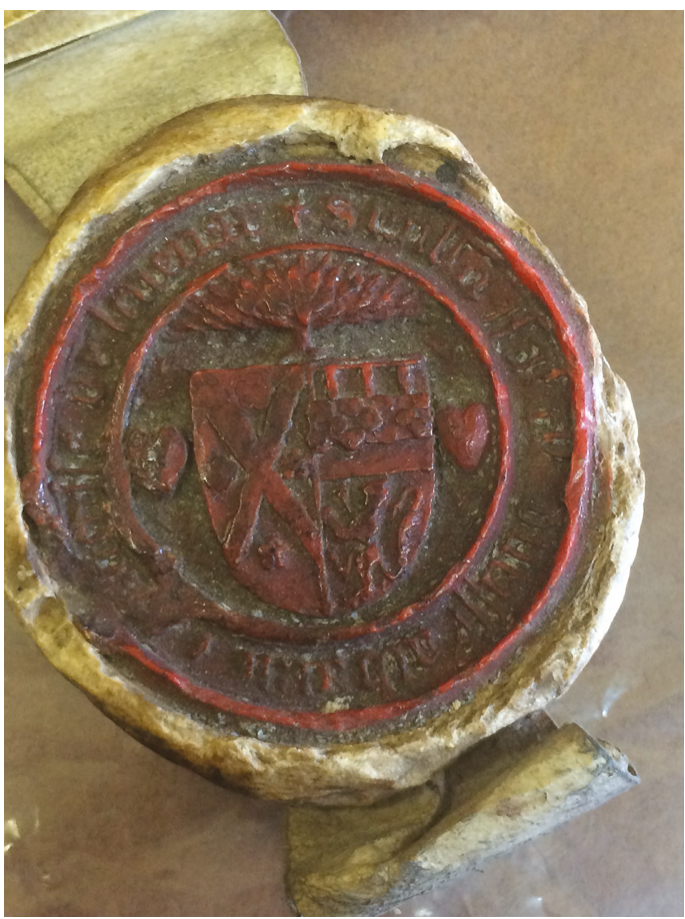

Illus 4A The SEAL IMPRESSION OF IsABElla, Duchess of Albany and Countess of Lennox. (C) National RECORDS OF SCOTLAND)

1987: 243-5). Her claims to these titles may have been in question, given the apparent forfeiture of the earldom and other titles upon the death of her male family members. The privileged right (dexter) side of the shield features the arms of Lennox, her natal kindred - a saltire between four roses - and the left (sinister) side is quartered to show her marital lineage and territorial holdings, with the top bearing the arms of Stewart of Menteith - a fess chequy with a label of four points in chief - and the bottom representing the earldoms of Fife and Menteith - a lion rampant. Thus, the seal communicated her claims to the associated territories and privileges of each represented lineage; it created a visual link to the title found in her charter.

The hearts displayed on either side of the shield, an iconography that had strong associations with the Douglas lineage, are difficult to parse in the context of the duchess's seal. The red heart, borne by the first Earl of Douglas and his

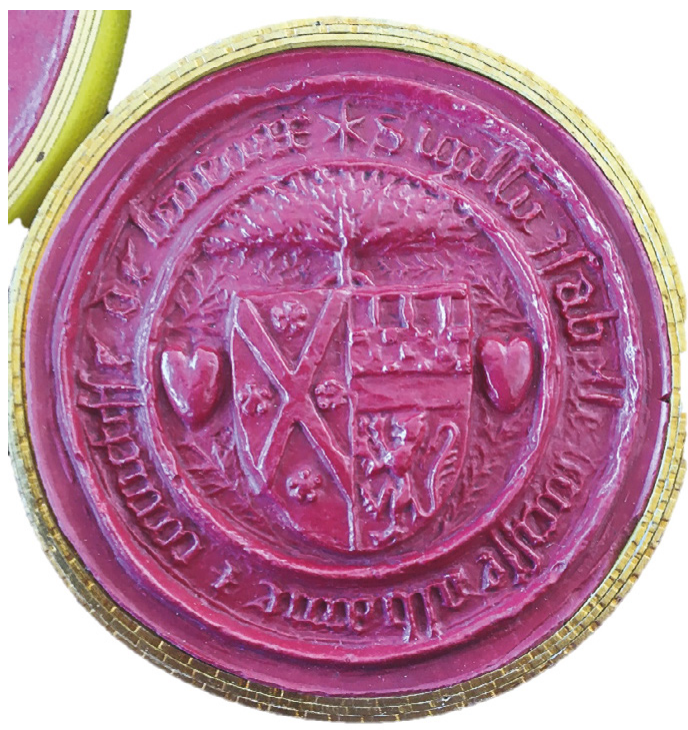

ILLus 4B The seal cast of Isabella, Duchess of Albany and Countess of Lennox. The seal features a large impaled shield, which hangs from a tree at the top of the seal. There are hearts on either side of the shield. The shield's arms:

Dexter: a saltire between four roses; Sinister: (quartered) top bearing a fess chequy with a label of three points in chief; bottom bearing a lion rampant. (C) National Records of Scotland)

descendants thereafter, commemorated and celebrated James, Lord Douglas, who carried Bruce's heart with him on crusade. Richard Holland's The Buke of the Howlat, written as Douglas propaganda in the 1450 s, explains the chivalric significance of the heart, which had reputedly been thrown at a Moorish force by Sir James at the Battle of Teba (1330) (Holland 1987: 66; Drummond 1994: 49; Brown 1997: 164-5). The heart is not used here as a heraldic device, however, and there is no Douglas connection for Isabella; thus, it likely had a different visual meaning. Moreover, the heart is not noted elsewhere as a common symbol in seal iconography in the period, when not deployed heraldically (Shiels \& Campbell 2011: 81-3).

The seal survives attached to charters issued after the duchess's release from custody in 1437, authenticating her acts during her widowhood 
in Lennox in the 1440s and 1450s, which leaves open the possibility that the seal was commissioned after her incarceration. The heart may be an allusion to the heart of Christ and, as such, a reflection of the duchess's personal religious devotion (Hartnell 2019: 138). It may also have had a more personal meaning for the duchess, a sign of her devotion to her predeceased kin, memorialising her relationship to the lineage and to the individuals killed in 1425 . There is evidence to suggest this was the case, as the seal was attached to a charter granting lands in the earldom of Lennox to Colin Campbell and Isabella's granddaughter, Mariota, in the good memory of her deceased son Walter Stewart of Albany, father of Mariota [in bone memorie Walteri Stewart de Albania filii mei carissimi $].{ }^{15}$ The seal survives, albeit as a fragment, attached to a religious donation of 1447 in which she memorialised her father, Duncan, Earl of Lennox [progenitoris nostri bone memorie Duncani comitis de Levenax.${ }^{16}$ These commemorations can also be traced in the pro anima clauses in some of the duchess's charters. In a 1451 donation to a priory in Glasgow, Duchess Isabella made the donation for the sake of her own soul, as well as the souls of her husband, father and sons, although this deed does not include a seal attached in situ. ${ }^{17}$ We might interpret this clause as politically motivated. Katy Jack has argued that the pro anima clause not only demonstrated the grantors' concern with the spiritual well-being of their predeceased kin, but also was important in the "promotion of lineal continuity, particularly if the grant was issued during a period of contested succession to an earldom or lordship, or where the authority of the ruling kindred was undermined or under threat' (Jack 2017: 154). The duchess's power in Lennox lands had been re-established by 1451; thus the charter does, indeed, assert her political claims. On a more personal level it created a connection between the duchess and her deceased family (Jamroziak 2010; Hodgson 2016: 109). This is explicitly articulated in the iconography of the heart, which was considered the seat of the human soul (Webb 2010: 2; Hartnell 2019: 135-6). The use of the heart as symbol would suggest that the duchess viewed herself as the living representation of her lineage, and memorialised her deceased kin as a way to express her connection to it. The symbology of the heart in the seal may communicate with, and contextualise, the commemorative pro anima clauses in her charters. Reading seal and charter together gives the iconography new meaning otherwise lost when the material evidence of each is considered separately from the other.

\section{THE SEAL OF MARGARET STEWART, COUNTESS} OF DOUGLAS

The issue of incongruity between an individual's circumstances and claimed titles/lineages within the seal warrants further consideration of the potential non-mimetic properties of the visual elements of women's seal designs. While communicating the identity of the sealer, seal designs could also seemingly be a departure from the socio-political reality of the sealer. Steve Boardman has drawn attention to the potential duplicity of women's seal designs in his discussion of Margaret Stewart, Countess of Angus and Mar's sigillographic rendering. Her seal features a standing female figure under a canopy, supporting with each hand a shield (Illus 5). ${ }^{18}$ The right (dexter) shield bears six cross crosslets fitchy, the arms of Mar, her marital kin. The left (sinister) bears a fess chequy surmounted by a bend with three buckles, her natal kin (Stewarts of Bunkle). Boardman suggested that 'in Margaret's case, the image was utterly deceptive and unrelated to the reality of the social and political networks in and through which she lived her life' (Boardman 2014: 58). From this perspective, the seal design, then, seems to convey aspirational or tenuous claims to territory and kinship. Ailes has suggested that heraldry could be used for 'misrepresentation' or 'disinformation' in particular situations (Ailes 2002: 83). In the context of sealing practice, Bedos-Rezak has argued that medieval seals were not merely involved in representing reality but in creating it (Bedos-Rezak 2008: 1). However, when the seal of Margaret Stewart is read in its context, it does not matter that the countess's kinship networks did not necessarily align with her sigillographic persona. Her seal 
legend identified her as ' $S$ ' MARGUERITE DE SENESCHALLE CONTESSE DE MARRE', which was visually reinforced by the display of the Mar arms in the favoured (right [dexter]) position within the seal's visual field. Both the text of the legend and the visual vocabulary of the Mar arms reinforced her title in the charter - which identified her as the Countess of Angus and Mar. Her rights to Mar came to her as a childless widow entitled to a widow's portion (terce) and, as such, her hold on lands and estates in the earldom was potentially open to legal dispute, challenge or negation with the successors to the earldom of Mar. These claims were potentially made more tenuous by her irregular and consanguineous relationship with the Earl of Douglas, which produced two illegitimate children while the earl was married to the female heir to Mar, also named Margaret (the countess's sister-inlaw). Negotiations between the eventual female heir to Mar, Isabella Douglas, and her half-siblings over their rights began in the 1390s. George Douglas, son of Countess Margaret Stewart, negotiated with Malcolm Drummond, the Countess of Mar's husband, regarding his rights to his mother's terce in $1398 .{ }^{19}$ Additionally, Countess Isabella Douglas provided a life rent to her half-sister Margaret Douglas (Robertson 1857: 730-1). The relationship between the Countess of Angus and Mar with her Mar kindred was complex, and she and her children negotiated access to Mar land and resources. Thus, the seal design of the countess asserted her claims within the earldom and reinforced her rights to her Mar terce. Her seal created a representational identity that the countess used to express her status and

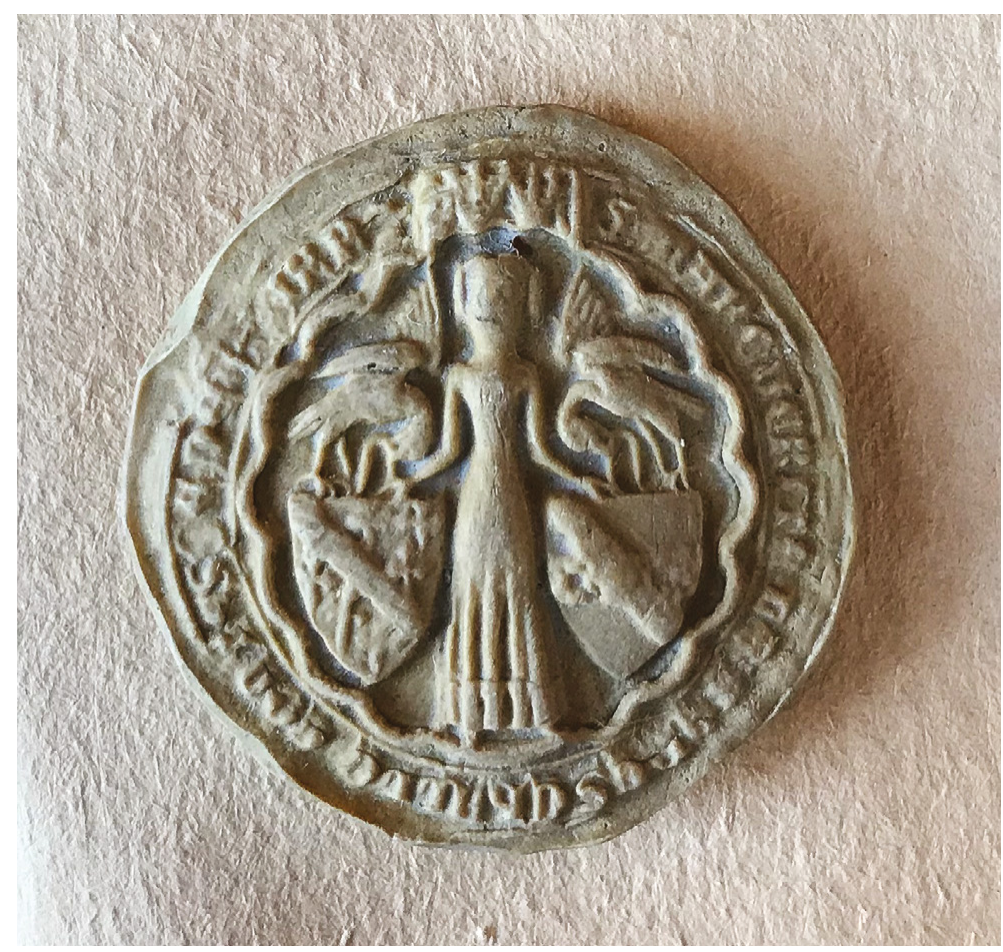

Illus 5 The seal cast of Margaret Stewart, Countess of Angus and Mar. The seal bears a standing female figure with hair covered under a canopy, supporting a shield with each hand. Resting on each shield is an eagle, holding the shield strap in its beak. The shields' arms: Dexter: a bend between six cross crosslets fitchy; Sinister: a fess chequy surmounted by a bend charged with three buckles. (C) Lyon Office, The Court of the Lord Lyon, Edinburgh; by kind permission of the Lyon Office) 
authority as widow and countess, and the visual display of the Mar arms was emphasised within her charter as well as her seal legend. While her kinship networks were somewhat different than what her seal design suggests, the latter nevertheless displayed her aspirations and ambitions as countess and reinforced her legal rights to Mar as widow. Her seal therefore contextualises her charter and vice versa, both objects, with their text and image, communicating together the elite status and authority of the Countess of Angus and Mar.

\section{THE SEAL OF EUPHEMIA LESLIE, COUNTESS OF ROSS}

Thus far, an intertextual reading of seal and charter has been relatively straightforward, even if the iconography or use of heraldic device needed further analysis, as the charter and seal survive together, and we can parse the way they functioned contextually. However, the medium of seals (wax) makes it difficult always to rely on survival of the original impression and charter together. While it is preferred to interpret the material in situ, we might trace how to employ antiquarian volumes and seal casts to reconstruct the context, recognising that there well may be potential contextual losses. The seal of Euphemia Leslie, Countess of Ross offers an opportunity to explore the methodological difficulties of an intertextual approach to seals and charters as well as show how the context of seal and charter might be reconstructed using antiquarian volumes, illustrations and seal casts.

The original impression of the Countess of Ross's seal survives attached to a 1394 charter issued in her name. Despite archival conservation efforts, the obverse is nearly obliterated, and the reverse shows only a small portion of the original visual field (Illus 6a, Illus 6b).$^{20}$ A plate illustration of the countess's seal was provided in Cosmo Innes's 1848 A genealogical deduction of the Family of Rose of Kilravock alongside the edited text of a charter also dated 1394 (Innes 1848: 123) (Illus 6c). While the image here does not convey the relief and detail of the original impression, its presence in the volume is useful, as it appears with the charter to which it was attached, so while both are not originals, Innes reproduced the context of the originals in this printed text. Usefully, Henry Laing made use of Innes's source material, and produced his resin cast of the Countess of Ross's seal from the same charter (Illus 6d). ${ }^{21}$ Seal casts are similar to detached original seal impressions, as they no longer have their specific context in which they were used. The illustration and the cast also do not include the reverse image of Countess Euphemia's seal, which was a part of the original impression, so there is some loss of her seal's meaning in its reproductions, either material or illustrative. While seal casts were made as later reproductions for seal catalogues, it is important to note that a seal cast is a three-dimensional copy of the original seal impression and, as such, we can treat it as carrying the same evidential worth as a seal impression, as long as the possible caveats above are acknowledged (Bedos-Rezak 1988: 352). Due to the nature of the evidence, its medium (wax) and its rate of survival from late medieval Scotland, seal casts are often all that remains of elite women's seals. Thus, we can use the exemplar of Euphemia Leslie to trace how we might use seal casts and illustrations, alongside seal catalogues and extant impressions to reconstruct context and meaning, while acknowledging the inherent limitations.

We can then turn to interpreting the seal design of the Countess of Ross similarly to the original impressions discussed above. Euphemia privileged her husband's lineage in her seal design, with the Leslie coat of arms (on a bend three buckles) occupying the right (dexter) position in the visual field. Her seal legend furthered this connection, reading, 'SIGILLU' EUFAMIE LESLEY DE ROS', in which she adopted the Leslie surname. She continued to use the Leslie surname following the death of her husband, Walter Leslie, in 1382 (Innes 1848: 123). The charter, from which the original impression hung, was dated 1394, over a decade after the death of Leslie. Although she outranked her husband as a countess, Leslie had been a chivalric hero, a successful crusader and a favourite at the court of David II. This relationship helped 


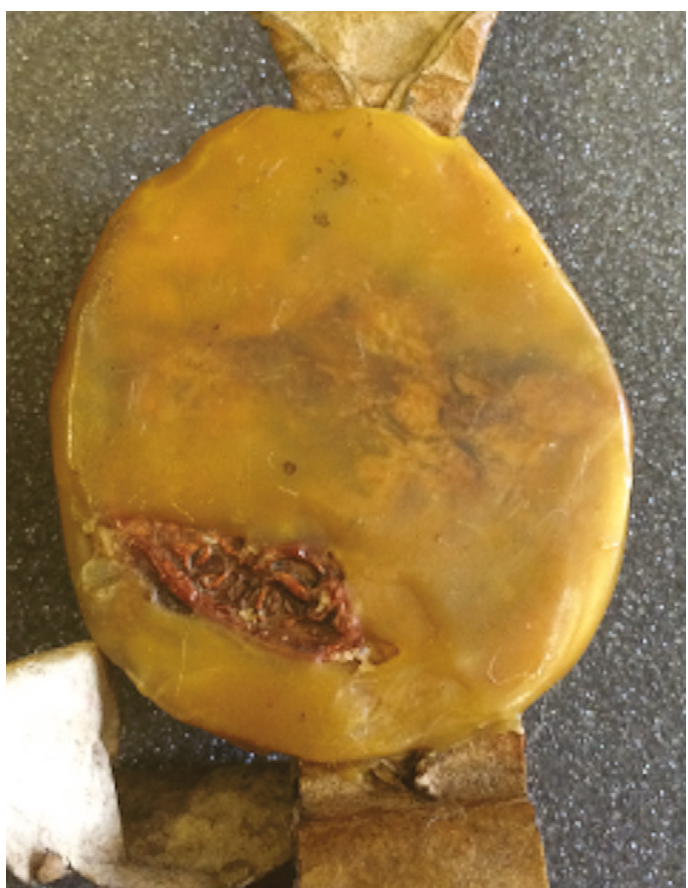

ILlus 6A The seal impression (obverse) of Euphemia Leslie, Countess of Ross. (C) Highland Archive Centre)

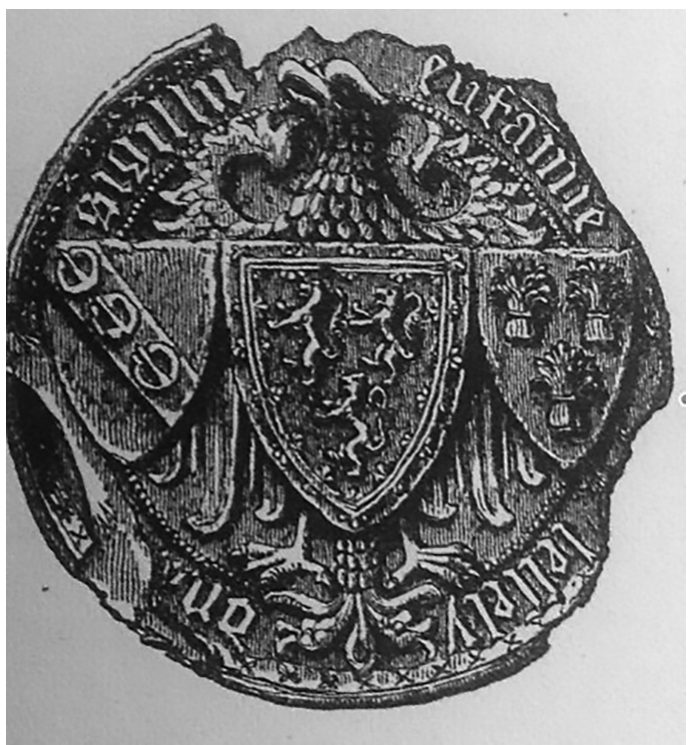

ILLus 6c The illustration of the seal belonging to Euphemia Leslie, Countess of Ross. (Courtesy of Rachel Meredith Davis)

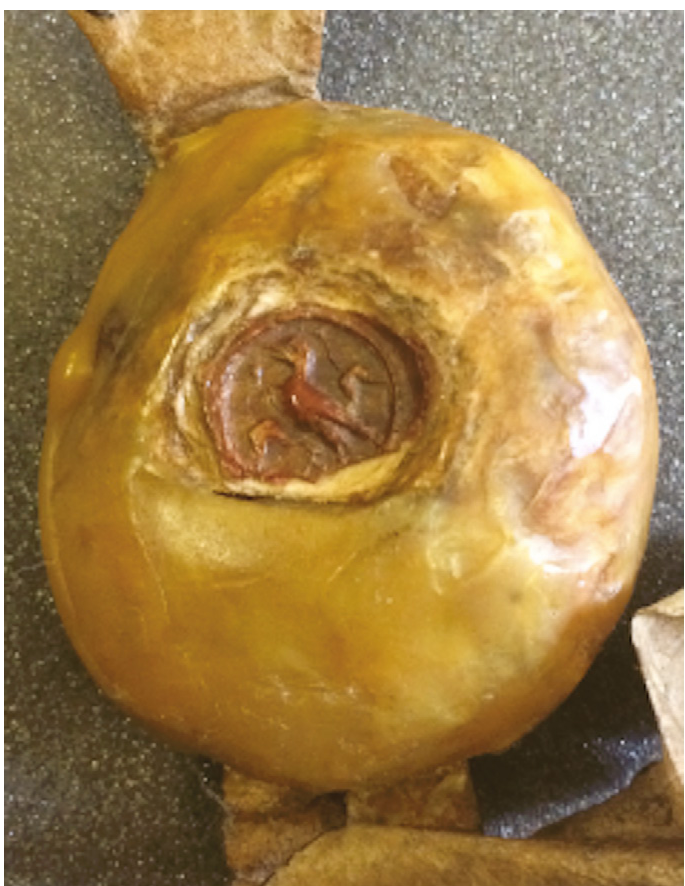

ILLus 6B The seal impression (reverse) of Euphemia Leslie, Countess of Ross, likely made with a signet ring. (C) Highland Archive Centre)

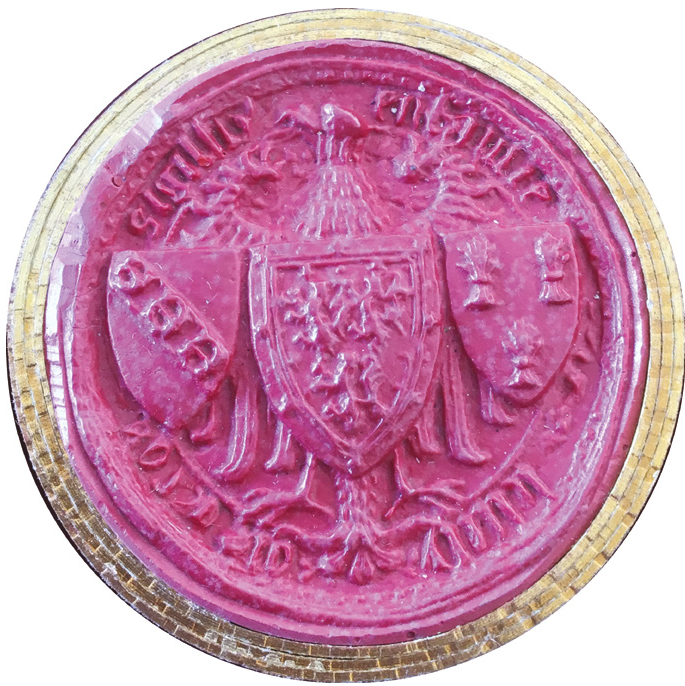

ILlus 6D The seal cast of Euphemia Leslie, Countess of Ross. The seal features an eagle displayed bearing on its breast three shields. The shields' arms: Centre: three lions rampant in a double tressure; Dexter: on a bend, three buckles; Sinister: three garbs. (C) National Records of Scotland) 
the countess and Leslie gain control of the earldom of Ross in the 1360s (Boardman 1996: 25). Euphemia's affiliation with his lineage (and chivalric reputation) was clearly thought to be important, even after his death. The specific charter to which this seal was attached was in fact a 1394 transaction between the countess and her brother-in-law, George Leslie of Rothes, but the seal, with its emphasis on her affinity with the Leslie family, would obviously have been used in a variety of contexts aside from direct dealings with her dead husband's kinsmen (Innes 1848: 123). The use of the Leslie surname alongside the Leslie arms may have been intended to benefit her son, Alexander Leslie, as heir to the earldom of Ross. For Euphemia (and others) emphasis on her status as widow and mother to Leslie children, rather than as the female heir of Ross, may have been seen as laying claim to a wider range of personal rights and benefits from her deceased husband's lineage. Additionally, the seal created a visual continuity and consistency between herself as a representative of the ancient Ross family and the new line of Leslie earls of Ross. As can be seen in the other examples, there is a careful and complex articulation of identity and elite status that is achieved through the interplay of word and image. The Countess of Ross's charters inform the meaning of the design of her seal and the design of her seal informs the meaning of her charter. Thus, the intertextual relationship of seal and charter uncovers significant meaning behind Scottish sealing practice and how both were employed in their contemporary contexts. Euphemia's seal is also a useful example of the way in which we might use seal catalogues and antiquarian volumes critically to engage with Scottish sigillographic material.

\section{THE THREAVE MATRIX AND THE SEAL OF MARGARET STEWART, DUCHESS OF TOURAINE, COUNTESS OF DOUGLAS, LADY OF GALLOWAY AND ANNANDALE}

The seal design of Margaret Stewart, Countess of Douglas, Lady of Galloway and Annandale (daughter of Robert III), presents us with a unique glimpse of the making process and identity construction which points to the active participation of elite women in promoting noble lineage and status through heraldic device. During the 1974-8 excavation of Threave Castle, a late 14th-century tower house belonging to the Black Douglas family, a seal matrix was found, possibly depicting a design of the duchess (Good \& Tabraham 1981: 109-11). That a matrix belonging to the duchess might be found at Threave is not surprising, since several of her extant charters were issued there. ${ }^{22}$ Now held in the National Museum of Scotland collections, it is unusual in the context of 15th-century Scotland, as seal matrices belonging to individuals are difficult to trace in the historical record compared to the prevalence of institutional matrices in collections (Illus 7a). ${ }^{23}$ This may owe something to the fact that matrices were personal objects that carried legal significance within medieval society. In their analysis of the Threave finds, Good \& Tabraham put forward the argument that the matrix was a potential forgery. However, this argument has not been thoroughly tested and there has been little further interpretation of the matrix as historical object since the initial archaeological analysis.

The Threave matrix allows a further discussion of the significance of the materiality of seals (and their matrices) as legal objects and issues of forgery. As argued earlier in this article, the seal was a literal material witness to the charter and both were linked in use by the physical tag of parchment from which the seal hung as well as the sealing clause that noted the seal as an extension of the issuer's legal personhood. In a recent study of everyday material culture in Scotland, Jenny Shiels and Stuart Campbell found that in relation to surviving seal matrices from medieval Scotland it was common to either break or score the surface of the matrix as a means of nullifying an individual's seal after death (Shiels \& Campbell 2011: 81). This is not the only context in which a matrix was damaged to nullify it as a functional legal object. It could also occur when lands were forfeited, signifying the damaged reputation of the owner (Tonnochy 1952: xlv-xlvi). The seriousness with which forgery was treated indicates the importance of a seal as 


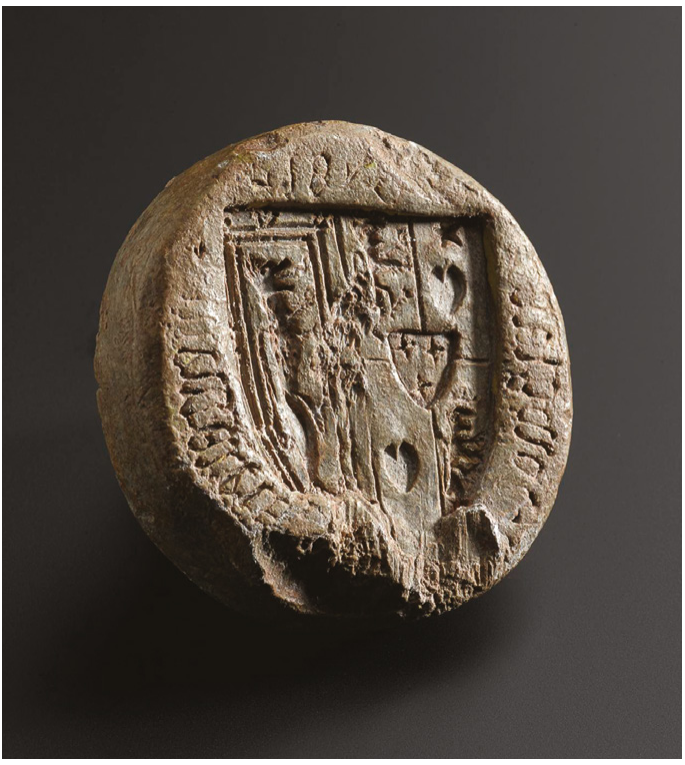

ILlus 7A The Threave matrix attributed to Princess Margaret of Scotland. A crude armorial seal matrix bearing a quartered shield. The shield's arms: Dexter: 1 st and 4th a lion rampant; 2 nd and 3rd a heart on a chief three stars, surtout: three fleurs-de-lis (or three mullets?); Sinister: a lion rampant within a double tressure. (C) National Museums Scotland)

an authenticating tool and the representation of an individual's personhood, as anyone accused of falsifying charters could be treated the same as an individual guilty of treason. Punishment for the forgery of seals and charters was differentiated based on the social status of the victim: forgery and falsification of the king's seal or charter was punished more severely than that of a lord, with light punishment for the falsification of personal charters and seals (Neville 2010: 84; Cooper 1947: 199-200, 260-1). Janet Felton, for example, dealt with a forgery of her seal in 1481, issuing a notarial instrument that retracted all charters, sasines and other writs relating to her lands of 'Bowfurde' and 'Ard' that had been granted by the deceased David Stewart of Rosyth, and his son, Henry, who she alleged had obtained her seal fraudulently and fabricated documents with it. ${ }^{24}$ The evidence demonstrates the potency of matrices and their impressions as authenticators

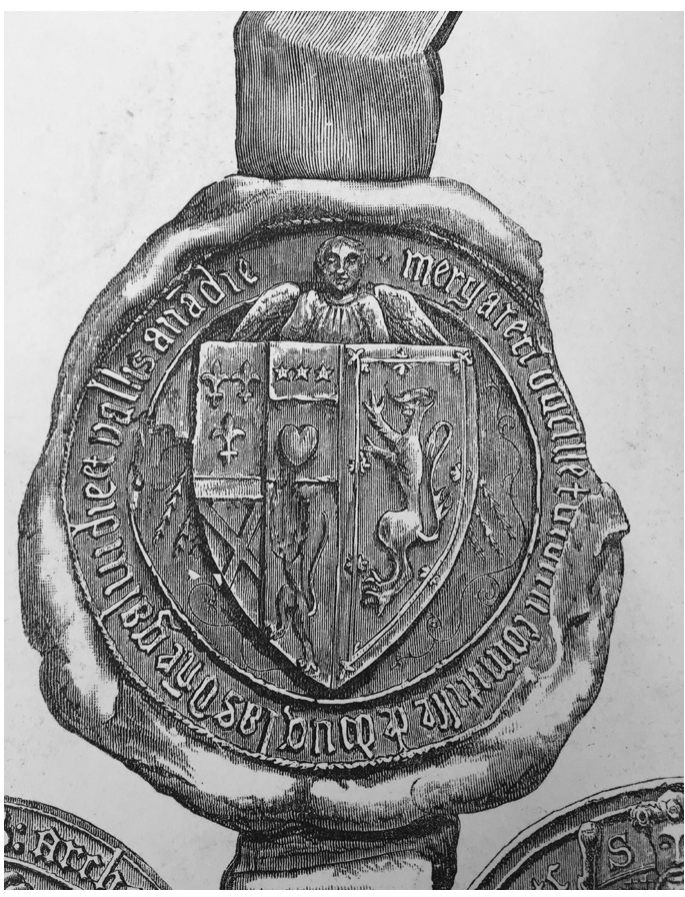

ILLUS 7B The illustration of the seal belonging to Margaret Stewart, Countess of Douglas, Lady of Galloway and Annandale. A seal bearing impaled arms on a shield supported by an angel with foliage ornament. The shield's arms: Dexter: 1st three fleurs-de-lis; 2 nd a heart on a chief three stars; 3rd a saltire in chief; 4th a lion rampant crowned; Sinister: a lion rampant in a double tressure. (Courtesy of Rachel Meredith Davis)

of a donor's acts. It also shows that forgery of a seal was a grave offence, and any interpretation of the Threave matrix as forgery ought to be done with caution.

There are several key differences between the matrix and the duchess's eventual seal that ought to be discussed further, which requires a degree of reconstructed context in order to analyse the seal's meaning alongside the Duchess Margaret's charters. I have yet to locate a surviving original impression of the duchess's seal, but there is an illustration in Sir William Fraser's The Douglas Book, which was used by Stevenson \& Wood as well as the other Scottish seal catalogue compilers (Fraser 1885, vol 2: 552) (Illus 7b). ${ }^{25}$ 
It is worth noting that seal illustrations are used within current sigillographic methodology when the original material might be lost or damaged (Whatley 2019: 5). The way in which her territorial and lineage claims are displayed differ from the arrangement of the coats of arms in the matrix. In the illustration of the duchess's seal, the design features the arms of Touraine - three fleurs-de-lis - in the first quadrant on the right (dexter) side of the shield. The placement of these arms gives priority to the prestige of the newly acquired territory. In the supposed earlier design depicted in the matrix, the arms of Touraine are surtout in the right (dexter) side of the shield. However, Good \& Tabraham identified the arms differently, suggesting that this shield bears three mullets (stars) rather than three fleurs-de-lis, a reference, they posited, to the arms of the lordship of Bothwell in south Lanarkshire that her husband, the Earl of Douglas, may have had claim to through his mother Joanna Moray's inheritance (Good \& Tabraham 1981: 110). ${ }^{26}$ Identifying the arms as such, they dated the matrix to 1406 , making the assumption that she adapted her arms around the same time as a supposed adaptation by her husband (Good \& Tabraham 1981: 111). Good \& Tabraham's interpretation of the duchess's matrix perhaps assigns too much significance to the lordship of Bothwell. As McAndrew has noted, the Bothwell/Moray arms were also dropped from the seal representations of the earls of Douglas, after the death of the third earl (Margaret's father-in-law) (McAndrew 1977: 5). Thus, her husband did not adapt the Bothwell arms in his seal design. The fact that the Bothwell/Moray arms do not appear in seal designs of later earls of Douglas casts doubt as to whether the arms are depicted in the duchess's seal design.

Given the size of the Threave matrix and the condition of it, there is room for interpretation of what arms are actually depicted and whether the surtout shield bears the Bothwell/Moray arms as suggested by Good \& Tabraham or the arms of the duchy of Touraine as I propose here. The duchess's eventual seal design shares stylistic elements with the seal of her mother-in-law, Joanna Moray, Countess of Douglas and Lady of Bothwell. The angel supporter in the duchess's seal design is similar to the angel supporter in the seal of the countess. ${ }^{27}$ The seal of her mother-inlaw also bears the arms of Bothwell/Moray on the left (sinister) shield, which may be compared to the heraldic device of the duchess's seal. It is important to note that the seal design of Joanna Moray intertextually communicated her relationship to Bothwell in the visual field of the seal, the seal legend, and her extant charters. The Bothwell arms tied visually with her seal legend, which read, ' $S$ ' IONETE CO[M]ITISSE DE DOUGLAS DNE BOT[HUIL]'. Both of these corresponded to her title in the charter itself, which read 'Joanna, Countess of Douglas, Lady of Galloway and Bothwell [Johanna comitissa de Douglas domina Gallvidie et de Bothvill]'. ${ }^{28}$ Thus, word and image corroborated and communicated her Moray lineage and claim to Bothwell estates. Representation of the Bothwell/Moray arms may not, in any case, have been as significant for Duchess Margaret given the Douglas acquisition of the more prestigious title by her husband. The arms, instead, likely depict three fleurs-de-lis, representative of the duchy of Touraine, which was a significant acquisition for the Douglases. The matrix, then, might date to 1424, when the duchy of Touraine was granted to Archibald, Earl of Douglas for his service to the King of France in the Hundred Years War. Stevenson has drawn attention to the importance and significance of the acquisition of Touraine for the Douglas family. She argued that the duchy 'was a position of particular cachet, as no other foreign noble, nor indeed Frenchman connected to the royal house, had been given a ducal rank by a late-medieval French king' (Stevenson 2007: 206). Given the importance of the duchy and the prestige attached to it, having been granted for Douglas's military service, the status which these new arms afforded was an obvious choice for addition to the duchess's seal design and suggest that the matrix is evidence of the commissioning process following the acquisition of this title and associated territory.

The arrangement of arms is not the only difference between the matrix and the later seal design. The legend reads 'sig mergareta dowglas', whereas the eventual legend 
states, 'MERGARETE DUCISSE TURONII COMITISSE DE DOUGLAS DNE GALUIDIE ET VALLIS ANADIE', which corresponds to the way in which the duchess was identified in her charters as well, which read 'Margaret, Duchess of Touraine, Countess of Douglas, Lady of Galloway and Annandale [Mergareta ducissa Turonie comitissa de Douglas domina Galividie et Vallis Anandie]'. ${ }^{29}$ While this analysis requires a degree of reconstructed context, as we are working with an illustration of her seal, rather than material evidence, we can use the legend and title used in her charters as evidence that the arms depicted in the matrix are not the arms of Moray/Bothwell, as she did not claim them among her titles. Rather, the arms are that of Touraine, which was a title she used in her charters and eventual seal legend. The placement of the arms corroborates this too: the configuration of her arms in the right (dexter) portion of the shield visually construes her title given in her charters in rank order, where the arms of Touraine (three fleurs-de-lis) and Douglas (a heart in chief three stars) are prioritised visually, which reveals the importance of these in terms of status and authority. The arms presented surtout in the matrix produce the same effect of awarding the arms primacy, which further makes the case that they are an earlier experimentation with placement of the Touraine arms. The material of the matrix (lead), the legend and the rather crude rendering suggest it may be considered a prototype for what would eventually become the duchess's seal design and give us valuable insight into the active participation of women in the promotion of elite status and authority through heraldic device. Moreover, the historical meaning of these objects is fully realised by reconstructing the context of the duchess's final seal design and charters, which is lost when the object is considered in isolation from other material evidence.

\section{CONCLUSIONS}

This article has made several points relating to the significance of seals and charters in the communication and legitimation of elite status and authority in 14th- and 15th-century Scotland. More broadly, it has been shown that it is no longer tenable to use 19th- and 20th-century Scottish seal catalogues as substitutes for the material evidence. To do so is to overlook the deficiencies relating to completeness and accuracy highlighted by the compilers themselves. Thus, the use of the Scottish seal catalogues as a primary source raises critical methodological issues within modern scholarship. As this article has shown, instances of misidentification and the existence of seal impressions and seal casts previously missed out in the catalogues indicates that the Scottish seal catalogues should be a starting point for investigations into Scottish seals and sealing practice, rather than an end point. Additionally, continued use of Scottish catalogues ought to engage critically with the methods of compilers and highlight issues with reliability and comprehensiveness.

The seal operated in contexts beyond the charter as a symbol of status and authority as well as a personal object (Campbell 2013: 192). However, investigations into the contexts in which seals have been used often overlook the primary legal function of the seal as a method of authenticating the donor's act. The seal as authenticator of charter, which produced a sealed charter considered legally valid and authentic, meant that the relationship between seal and charter was an interdependent one. It is important, then, to consider the relationship and intertextual communication of word and image of both seal and charter in order to understand the full meaning represented within the seal's visual field. Contextual analysis with charters is not often undertaken in sigillographic study, which tends to view sealing practice in isolation or in comparison with other representational visual media. This article has traced the usefulness of an intertextual approach in six examples of seals belonging to Scottish countesses in the 14th and 15th centuries, and demonstrated the important legal function of the seal as object attached to the charter. Additionally, it has formulated a template with which seal casts and antiquarian volumes might be used in reconstructing the contemporary context of seal and charter when the evidential record is patchy. The 
evidence of elite Scottish women's seals from the later Middle Ages shows the complex and nuanced uses of heraldic device by women in their articulation of relationships to noble lineage as well as claims to titles, land and resources. Significantly, this study shows that women's seals still hold valuable promise to researchers beyond what Bedos-Rezak termed the 'semantics of the female image' and that analysis of heritable insignia and its use among the female nobility is a rich vein of further research into the ontological meaning the seal (Bedos-Rezak 1990: 11). The use of heraldry and other iconography promoted political links, rights to property by birth and marriage, claims to land and leadership positions, as well as commemorating personal links to deceased family. None of these features can be reduced to a formula for sealing practice. Rather they need to be parsed within the context of an individual elite woman's contemporary environment, considering the material evidence of seal and charter together.

\section{ACKNOWLEDGEMENTS}

I thank my PhD supervisors, Dr Cordelia Beattie and Professor Steve Boardman, for their comments and encouragement during the evolution of this research. I am also grateful to Dr Bill Aird for his critiques of this work in its early stages. I would also like to thank Dr Rick Sowerby and Professor Katie Stevenson, my PhD examiners, who both pushed my thinking further on identity in sealing practice. I thank Dr Alice Blackwell, National Museums Scotland, for facilitating my viewing of the Threave matrix and for her discussions with me about the matrix as well as her encouragement as I developed this article. I thank Dr Alan Borthwick of the National Records of Scotland, Jackie Higginson and Russell Hunter of the Court of the Lord Lyon, and Julian Harrison of the British Library for facilitating my search for Scottish seal casts. I thank Ingrid Thomson, archivist of the Glamis Castle Archives, for being so generous with her time and knowledge as I carried out research at Glamis. I thank my anonymous reviewers for their insightful comments that pushed my thinking further about women's seals. The images reproduced here were generously funded by a Scottish Historical Review Trust bursary.

\section{NOTES}

1 NRS Papers of the Earls of Morton, GD150/20.

2 The seals and heraldry therein are read from the perspective of the sealer (bearer of arms) rather than the viewer. This interpretation is accepted use in both heraldry and sigillography.

3 NRS Seal casts, matrices, and detached seals, RH17/1. These are located at Thomas Thomson House.

4 These plaster casts remain in drawers in the Lyon Clerk's Office, Court of the Lord Lyon, Edinburgh. NB: There are some missing, with unknown whereabouts.

5 My thanks to my anonymous reviewer for drawing my attention to this.

6 BL: Seal XLVII 1313. The original impression is attached to NRS Papers of the Smythe Family of Methven, Perthshire, GD190/3/68, a charter that dates from 1366, which was used for the analysis here.

7 'New' seals identified during this research or otherwise missing from earlier Scottish seal catalogues: the seal of Euphemia de Gohame, BL Seal XLVII 1623; the seal of Euphemia Stewart, Countess palatine of Strathearn, NRS Papers of the Cuninghame Graham Family of Ardoch, Dunbartonshire, GD22/2/1; the seal of Mary (Princess of Scotland), Countess of Angus and Lady of Loghram, NRS Papers of the Kennedy Family, Earls of Cassillis (Ailsa Muniments), GD25/2/3; the seal of Muriel Chisholm, NRS Dunbar of Westfield, GD466 Bundle 1/16 (formerly NRAS 3094/11); the seal of Katherine de Beaumont, Countess of Atholl, TNA E 42/494 (also identified by Ailes 2010) - her claim to Atholl was via her husband, David Strathbogie, who was a supporter of Edward Balliol (the earldom of Atholl had been forfeit since 1320); the seal of Mary 
de Monthermer, Countess of Fife, TNA E 43/271; the seal of Elizabeth Comyn, TNA E 40/4962.

8 NRS Papers of the Erskine Family, Earls of Mar and Kellie, GD124/1/123.

9 NRS Papers of the Campbell Family, Earls of Breadalbane (Breadalbane Muniments), GD112/25/2.

10 Seal of Agnes Randolph, Countess of March and Moray, attached to Durham Cathedral Archives, DCD Misc. Ch. 792 (Durham Cathedral seal catalogue 2886). While the original impression and charter were consulted in the course of this research, the seal cast is used here in the illustration.

11 Durham Cathedral Archives, DCD Misc. Ch. 792.

12 NRS Dunbar of Westfield, GD466 Bundle $1 / 6$. A cast is also held by the British Library, BL Seal XLVII 1626. The seal impression of Janet Dunbar, Countess of Moray, Lady of Frendraught and Crichton features a quartered shield with foliage surrounding the shield. The shield's arms: 1st quarter: three cushions lonzengeways (indistinct) within a double tressure flory, counterflory; 2nd quarter: a lion rampant; 3rd quarter: a saltire in chief; 4th quarter: a fess chequy between three cinquefoils.

13 NRS GD466 Bundle 1/6.

14 NRS GD112/25/2.

15 Ibid.

16 NRS Papers of the Maule Family, Earls of Dalhousie, GD45/16/3045.

17 NLS Adv. MSS, 19.2.20, f 33v.

18 Seal of Margaret, Countess of Angus and Mar, attached to Durham Cathedral Archives, DCD Misc. Ch. 653 - (Durham Cathedral seal catalogue 2741). While the original impression and charter were consulted in the course of this research, the seal cast is used here in the illustration.

19 NRS Papers of the Erskine Family, Earls of Mar and Kellie, GD124/1/120.

20 NRS Papers of the Munro Family of Foulis, GD93/15.

21 NRS Seal casts, matrices, and detached seals, RH17/1, no. 499 (drawer no. 20).
22 NRS: Miscellaneous Transcripts etc., Individual Documents, RH1/2/192; RMS, vol 2, 16 (nos. $86 \&$ 87); 26 (no. 133); 58-9 (no. 255).

23 NMS H HXA. 86.

24 Glamis Castle Archives, 14/3.

25 I have pursued the original impression in the research for this study. I consulted the material used by Sir William Fraser in his editing of the volume, but met with negative results (NRS: RH17/1 and NLS: MS 72).

26 It is important to note that Good \& Tabraham cite The Scots Peerage here to make their case rather than any charters that may explain the use of the Bothwell arms. For a discussion of the differences in heraldic device between different branches of the Moray family, including the Bothwell lineage, see McAndrew (2010).

27 NRS: Title deeds of the Swinton Family of Swinton, Berwickshire, GD12/15. The seal of Joanna Moray, Countess of Douglas, Lady of Galloway and Bothwell features an angel supporting two shields, with a flower between the bases of the shields. Dexter: parted per pale; dexter: a heart on a chief of three stars; sinister: a lion rampant crowned; sinister: three mullets.

28 NRS: GD12/15.

29 NRS: RH1/2/192.

\section{ABBREVIATIONS}

RMS: Registrum Magni Sigilli Regum Scotorum.

Ed. J M Thomson et al. 1882-1914, 11 vols. Edinburgh: HM General Register Office.

\section{REFERENCES}

DOCUMENTARY SOURCES

BL: British Library

BL 'Laing Casts', Seal XLVII 1313. Seal cast of Margaret Stewart, Countess of Angus. 


\section{DCD: Dean and Chapter of Durham, Durham}

\section{Cathedral Archives}

DCD Misc. Ch. 653: Seal of Margaret, Countess of Angus and Mar, attached to Durham Cathedral Archives, DCD Misc. Ch. 653 (Durham Cathedral seal catalogue 2741).

DCD Misc. Ch. 792: Seal of Agnes Randolph, Countess of March and Moray, attached to Durham Cathedral Archives, DCD Misc. Ch. 792 (Durham Cathedral seal catalogue 2886).

\section{Glamis Castle Archives}

Glamis Castle Archives, 14/3. Notarial instrument (1481) narrating a reduction by Janet Fenton, widow, regarding the fraudulent use of her seal.

\section{NLS: National Library of Scotland}

NLS Adv. MSS, 19.2.20, f 33v. 18th-century transcription of a 1451 donation charter of Isabella, Duchess of Albany and Countess of Lennox.

\section{NMS: National Museum of Scotland}

NMS H HXA. 86. The Threave matrix.

\section{NRS: National Records of Scotland}

NRS GD12/15, Title deeds of the Swinton family of Swinton, Berwickshire. Precept of sasine by Joanna Moray, Countess of Douglas, Lady of Galloway and Bothwell, to her son Archibald Douglas (1400/1).

NRS GD22/2/1, Papers of the Cuninghame Graham Family of Ardoch, Dunbartonshire. Confirmation charter of Euphemia Stewart, Countess palatine of Strathearn (1401).

NRS GD25/2/3, Papers of the Kennedy Family, Earls of Cassillis (Ailsa Muniments). Letters of assignation by Mary Stewart, Countess of Angus and 'Lady of Loghram' (1459).

NRS GD45/16/3045, Papers of the Maule Family, Earls of Dalhousie. Confirmation charter of Isabella, Duchess of Albany and Countess of Lennox (1447).

NRS GD93/15, Papers of the Munro family of Foulis. Charter by Euphemia, Countess of Ross (1394).

NRS GD112/25/2, Papers of the Campbell Family, Earls of Breadalbane (Breadalbane
Muniments). Charter by Isabella, Duchess of Albany and Countess of Lennox (1440).

NRS GD124/1/120, Papers of the Erskine Family, Earls of Mar and Kellie. Indenture agreement (in Scots) between Malcolm Drummond, Lord of Mar and Garioch, and George Douglas, Earl of Angus (1398/9).

NRS GD150/20, Papers of the Earls of Morton. Charter by Isabella, Countess of Fife (1369). NRS GD190/3/68, Papers of the Smythe Family of Methven, Perthshire. Confirmation charter by Margaret Abernethy, Countess of Angus (1366).

NRS GD466 Bundle 1/6, Dunbar of Westfield (formerly NRAS 3094/15). Charter by Janet Dunbar, Countess of Moray, Lady of Frendraught and Crichton (1454).

NRS RH1/2/192, Miscellaneous Transcripts etc., Individual Documents. Charter by Margaret, Duchess of Touraine, Countess of Douglas, Lady of Galloway and Annandale to the Franciscan friars of Dumfries (1425).

NRS RH17/1, Seal casts, matrices and detached seals. Seal casts described in Henry Laing's Descriptive Catalogue of Scottish Seals (1850) and other seal casts and detached seals.

\section{TNA: The National Archives, Kew}

TNA Exchequer: Treasury of Receipt: Ancient Deeds, Series A, E 40/4962. Release by Elizabeth Comyn to Edward II.

TNA Exchequer: Treasury of Receipt: Ancient Deeds, Series AS, E 42/494. Letter of attorney from Katherine de Beaumont, styled Countess of Atholl (1359).

TNA Exchequer: Treasury of Receipt: Ancient Deeds, Series WS, E 43/271. Letter of attorney from Mary, Countess of Fife (1337).

TNA Supplementary Finding Aids from The National Archives, QFA 1/19. Index to seals: Personal Equestrian (owner on horseback). Personal Armorial: Women (coat of arms).

\section{SECONDARY SOURCES}

Ailes, A 2002 'Heraldry in medieval England: symbols of politics and propaganda', in Coss, P \& Keen, M (eds) Heraldry, Pageantry and 
Social Display in Medieval England, 83-104. Woodbridge: Boydell \& Brewer.

Ailes, A 2010 'Scots heralds and heraldry in The National Archives (UK)', The Double Tressure: Journal of the Heraldry Society of Scotland 33: 2-36.

Allen, G 2011 Intertextuality. New York: Routledge.

Armstrong, J W 2009 'The development of the Office of Arms in England, c. 1413-1485', in Stevenson, K (ed) The Herald in Late Medieval Europe, 9-28. Woodbridge: Boydell \& Brewer. Augustine 1997 On Christian Teaching. R P H Green (tr). Oxford: Oxford University Press.

Bedos-Rezak, B 1988 'Medieval seals and the structure of chivalric society', in Chickering, $\mathrm{H} \&$ Seiler, T H (eds) The Study of Chivalry: Resources and Approaches, 313-72.

Kalamazoo, MI: Consortium for the Teaching of the Middle Ages.

Bedos-Rezak, B 1990 'Medieval women in the French sigillographic sources', in Rosenthal, $\mathrm{J} \mathrm{T}$ (ed) Medieval Women and the Sources of Medieval History, 1-36. Athens, GA: University of Georgia Press.

Bedos-Rezak, B 2000 'Medieval identity: a sign and a concept', American Historical Review 105(5): 1489-533.

Bedos-Rezak, B 2008 'In search of a semiotic paradigm: the matter of sealing in medieval thought and praxis', in Adams, N, Cherry, J \& Robinson, J (eds), Good Impressions: Image and Authority in Medieval Seals, 1-7. London: British Museum.

Bedos-Rezak, B 2011 When Ego Was Imago: Signs of Identity in the Middle Ages. Leiden: Brill.

Bertie, D M 2018 The Heraldry of Bishops in Scotland. Edinburgh: Heraldry Society of Scotland.

Boardman, S 1996 The Early Stewart Kings: Robert II and Robert III, 1371-1406. East Linton: Tuckwell Press.

Boardman, S 2014 'Lords and women, women as lords: the career of Margaret Stewart, Countess of Angus and Mar, c.1354-c.1418', in Boardman, S \& Goodare, J (eds) Kings, Lords and Men in Scotland and Britain, 1300-1625. Essays in Honour of Jenny Wormald, 37-58. Edinburgh: Edinburgh University Press.
Bower, W 1987 Scotichronicon. D E R Watt (ed). Aberdeen: Aberdeen University Press.

Broun, D (ed) 2011 The Reality behind Charter Diplomatic in Anglo-Norman Britain. Studies by Dauvit Broun, John Reuben Davies, Richard Sharpe and Alice Taylor. https://paradox.poms. ac.uk/ebook/index.html. Accessed 4 May 2021.

Brown, M 1997 ، "Rejoice to hear of Douglas": The House of Douglas and the presentation of magnate power in late medieval Scotland', The Scottish Historical Review 79(208): 161-84.

Buchanan, K \& Dean, L 2016 'Representations of authority: an introduction', in Buchanan, K \& Dean, L with Penman, M (eds) Medieval and Early Modern Representations of Authority in Scotland and the British Isles, 1-15. London: Routledge.

Caldwell, D H 1993 'Lead matrices of the 16th and early 17th century', Proc Soc Antiq Scot 123: 373-80.

Campbell, S 2013 'The language of objects: material culture in medieval Scotland', in Hammond, M (ed) New Perspectives on Medieval Scotland, 1093-1286, 183-202. Woodbridge: Boydell \& Brewer.

Caudrey, P J 2019 Military Society and the Court of Chivalry in the Age of the Hundred Years War. Woodbridge: Boydell \& Brewer.

Clanchy, M T 1993 From Memory to Written Record: England 1066-1307. Oxford: Wiley.

Cooper, T M (ed) 1947 Regiam Majestatem and Quoniam Attachiamenta. Edinburgh: J Skinner \& Co.

Coss, P 2000 The Lady in Medieval England, 1000-1500. Stroud: Stackpole Books.

Crane, S 2002 The Performance of Self: Ritual Clothing and Identity during the Hundred Years War. Philadelphia: University of Pennsylvania Press.

Crouch, D 1992 The Image of the Aristocracy in Britain, 1000-1300. London: Routledge.

Crouch, D 2019 The Chivalric Turn: Conduct and Hegemony in Europe before 1400. Oxford: Oxford University Press.

Danbury, E 2008 'Queens and powerful women: image and authority', in Adams, N, Cherry, J \& Robinson, J (eds) Good Impressions: Image and Authority in Medieval Seals, 17-24. London: British Museum. 
Davis, R M 2020 'Elite Women and Power in Late Medieval Scotland, 1296-1458', unpublished $\mathrm{PhD}$ thesis, University of Edinburgh.

Drummond, P M 1994 'Bloody heart', The Double Tressure: Journal of the Heraldry Society 16: 41-51.

Eco, U \& Marmo, C 1989 On the Medieval Theory of Signs. Philadelphia: John Benjamins Publishing.

Ewan, E \& Nugent, J 2008 'Where is the family in medieval and early modern Scotland?' in Ewan, E \& Nugent, J (eds) Finding the Family in Medieval and Early Modern Scotland, 1-8. Aldershot: Ashgate.

Fraser, W (ed) 1885 The Douglas Book, vol 2. Edinburgh: T \& A Constable.

Glenn, V 2007 'A newly discovered Dunkeld seal', The Innes Review 58(2): 217-21.

Good, G L \& Tabraham, C J 1981 'Excavations at Threave Castle, Galloway, 1974-78', Medieval Archaeology 25(1): 90-140.

Hammond, M 2013 'Introduction: the paradox of medieval Scotland, 1093-1286', in Hammond, M (ed) New Perspectives on Medieval Scotland, 1-52. Woodbridge: Boydell \& Brewer.

Harris, B J 2009 'The fabric of piety: aristocratic women and care of the dead, 1450-1550', Journal of British Studies 48(2): 308-35.

Hartnell, J 2019 Medieval Bodies: Life, Death and Art in the Middle Ages. London: Wellcome Collection.

Harwood, S 2017 'Swans and Amazons: Penthesilea and the case for women's heraldry in medieval culture', The Medieval Journal 7(1): 61-87.

Hodgson, V A 2016 'The Cistercian Abbey of Coupar Angus, c.1164-c.1560', unpublished $\mathrm{PhD}$ dissertation, University of Stirling.

Holland, R 1987 'The Buke of the Howlat', in Bawcutt, P \& Riddy, F (eds) Longer Scottish Poems. Volume One, 1375-1650, 43-84. Edinburgh: Scottish Academic Press.

Holton, C T 2017 'Masculine Identity in Medieval Scotland: Gender, Ethnicity, and Regionality', unpublished $\mathrm{PhD}$ dissertation, University of Guelph.
Innes, C (ed) 1848 A Genealogical Deduction of the Family of Rose of Kilravock. Aberdeen: Spalding Club.

Jack, K 2017 'Decline and Fall: The Earls and Earldom of Mar, c.1280-1513', unpublished $\mathrm{PhD}$ dissertation, University of Stirling.

Jamroziak, E 2010 'Spaces of lay-religious interaction in Cistercian houses of Northern Europe', Parergon 27(2): 37-58.

Johns, S M 2003 Noblewomen, Aristocracy and Power in the Twelfth-Century Anglo-Norman Realm. Manchester: Manchester University Press.

Johns, S M 2015 'Seals, gender, identity, and social status in the late twelfth and early thirteenth centuries in Wales', in Solway, S (ed) Medieval Coins and Seals: Constructing Identity, Signifying Power, 271-80. Turnhout: Brepols.

Johns, S M 2016 'Seals, gender, identity, and social status', in Schofield, P R, New, E A, Johns, S M \& MacEwan, J A (eds), Seals and Society: Medieval Wales, the Welsh Marches, and their English Border Region, 91-104. Cardiff: University of Wales Press.

Jordan, E L 2015 'Swords, seals and coins: female rulers and the instruments of authority in thirteenth-century Flanders and Hainaut', in Solway, S (ed) Medieval Coins and Seals: Constructing Identity, Signifying Power, 229-46. Turnhout: Brepols.

Laing, H 1850 A Descriptive Catalogue of Impressions from Ancient Scottish Seals. Edinburgh: T \& A Constable.

Laing, H 1866 Supplemental Descriptive Catalogue of Ancient Scottish Seals. Edinburgh: T \& A Constable.

McAndrew, B 1977 'The 1453 seal of James Douglas, 9th earl of Douglas', The Double Tressure: Journal of the Heraldry Society of Scotland 2: 4-10.

McAndrew, B A 1999 'The sigillography of the Ragman Roll', Proc Soc Ant Scot 129: 663-752.

McAndrew, B 2010 'Heraldic investigations anent early Murray genealogy', Proc Soc Antiq Scot 140: 145-64.

McAndrew, B 2011 'The Single Eagle supporter in Scottish Armory', The Double Tressure: 
Journal of the Heraldry Society of Scotland 34: $72-6$.

MacDonald, W R 1904 Scottish Armorial Seals. Edinburgh: W Green.

Marshall, R K 1983 Virgins and Viragos: A History of Women in Scotland from 1080 to 1980. London: Collins.

Morsel, J 2002 'Personal naming and representation of feminine identity in Franconia in the later Middle Ages', in Beech, G T, Bourin, M \& Chareille, P (eds) Personal Name Studies of Medieval Europe: Social Identity and Familial Structures, 157-80. Kalamazoo, MI: Medieval Institute Publications, Western Michigan University.

Neville, C J 2005 'Women, charters and land ownership in Scotland, 1150-1350', The Journal of Legal History 26(1): 25-54.

Neville, C J 2010 Land, Law and People in Medieval Scotland. Edinburgh: Edinburgh University Press.

Neville, C J 2017 'Making a manly impression: the image of kingship on Scottish royal seals in the High Middle Ages', in Abrams, L \& Ewan, E (eds) Nine Centuries of Man: Manhood and Masculinity in Scottish History, 101-21. Edinburgh: Edinburgh University Press.

New, E 2008 'Biblical imagery on seals in medieval England and Wales', in Gil, M \& Chassel, J (eds) Pourquoi les sceaux? La sigillographie nouvel enjeu de l'histoire de l'art, 451-68. Lille: CRHEN-O.

New, E 2013 'Lleision ap Morgan makes an impression: seals and the study of medieval Wales', Welsh History Review 26(3): 327-50.

New, E A \& Schofield, P R 2016 'Introduction', in Schofield, P R, New, E A, Johns, S M \& MacEwan, J A (eds) Seals and Society: Medieval Wales, the Welsh Marches, and their English Border Region, 1-11. Cardiff: University of Wales Press.

Nolan, K 2009 Queens in Stone and Silver: The Creation of a Visual Imagery of Queenship in Capetian France. London: Palgrave Macmillan.

Ravilious, J P 2010 'The Earls of Menteith: Alexander, Earl of Menteith and Sir Alexander Abernethy', The Scottish Genealogist 57(3): $130-9$.
Robertson, J (ed) 1857 Antiquities of the Shires of Aberdeen and Banff, vol 4. Aberdeen: Spalding Club.

Saul, N 2009 Church Monuments in the Middle Ages. Oxford: Oxford University Press.

Saul, N 2011 Chivalry in Medieval England. Cambridge: Harvard University Press.

Shiels, J \& Campbell, S 2011 'Sacred and banal: the discovery of everyday medieval material culture', in Cowan, T J \& Henderson, L (eds) $A$ History of Everyday Life in Medieval Scotland, 1000-1600, 67-88. Edinburgh: Edinburgh University Press.

Stevenson \& Wood seal casts, The Court of the Lord Lyon, Edinburgh.

Stevenson, J H \& Wood, M 1940 Scottish Heraldic Seals: Royal, Official, Ecclesiastical, Burghal, and Personal. Glasgow: R Maclehose \& Co.

Stevenson, K 2006 Chivalry and Knighthood in Scotland, 1424-1513. Woodbridge: Boydell \& Brewer.

Stevenson, K 2007 'Contesting chivalry: James II and the control of chivalric culture in the 1450s', Journal of Medieval History 33(2): 197-214.

Stevenson, K 2009 'Jurisdiction, authority and professionalisation: the Officers of Arms of Late Medieval Scotland', in Stevenson, K (ed) The Herald in Late Medieval Europe, 41-66. Woodbridge: Boydell \& Brewer.

Stevenson, K 2014 Power and Propaganda: Scotland 1306-1488. Edinburgh: Edinburgh University Press.

Tonnochy, A B 1952 Catalogue of British SealDies in the British Museum. London: British Museum.

Webb, H 2010 The Medieval Heart. Princeton: Princeton University Press.

Weikert, K 2020 Authority, Gender and Space in the Anglo-Norman World, 900-1200. Woodbridge: The Boydell Press.

Whatley, L J 2019 'Introduction: approaches to medieval seals and sealing practice', in Whatley, L J (ed) A Companion to Seals in the Middle Ages, 1-16. Leiden: Brill.

Wormald, J 1985 Lords and Men in Scotland: Bonds of Manrent, 1442-1603. Edinburgh: John Donald. 